\title{
LOSING THE COLONIES: HOW DIFFERING INTERPRETATIONS OF THE BRITISH CONSTITUTION CAUSED THE AMERICAN REVOLUTION
}

\author{
A Thesis \\ presented to \\ the Faculty of California Polytechnic State University, \\ San Luis Obispo
}

In Partial Fulfillment

of the Requirements for the Degree

Master of Arts in History

by

Brian Flint

December 2010 
(C) 2010

Brian Flint

ALL RIGHTS RESERVED 


\section{COMMITTEE MEMBERSHIP}

TITLE: Losing the Colonies: How Differing Interpretations of the British Constitution Caused the American Revolution.

AUTHOR: Brian Flint

DATE SUBMITTED: March 2011

COMMITTEE CHAIR: Thomas Trice, PhD. Professor of History

COMMITTEE MEMBER: Robert Detweiler, PhD. Professor of History

COMMITTEE MEMBER: Kathleen Murphy, PhD. Professor of History 


\begin{abstract}
Losing the Colonies: How Differing Interpretations of the British Constitution Caused the American Revolution

Brian Flint

Faced with an economic crisis following the French and Indian War, the British Parliament, along with a young and inexperienced King George III changed its longstanding policy towards the North American colonies. Prior to 1763, Parliament allowed the colonies to generally govern themselves. After 1763, Parliament began to pass legislation aimed at increasing revenue received from the colonies. As the colonies protested these new taxes on constitutional grounds Parliament began a process of implementing and repealing different attempts at controlling the economic system in the colonies. Due to differing interpretations of the British Constitution regarding Parliament's authority over the colonies, resistance to the change in policy by Parliament escalated in the 1760s and 1770s. It is this difference in interpretation that eventually led the colonists to open rebellion in 1775.
\end{abstract}




\section{ACKNOWLEDGMENTS}

I am indebted to Dr. Robert Detweiler and Dr. Kathleen Murphy for providing direction in guidance on this thesis. They were able to direct me to ongoing research on this subject that I had missed in early drafts. They also offered valuable advice on specific aspects of the history of Colonial America which greatly enhanced this thesis. As my Graduate Advisor, Dr. Thomas Trice was a constant source of guidance, encouragement, and knowledge as I progressed through the program. Without these professors, I would not have been able to produce this thesis. In general, the professors of the History Department that I had the pleasure of working with have made this an enjoyable and enriching process. Of course, without the constant support of my parents, David and Ella Flint, success in a program such as this would have been impossible. 


\section{TABLE OF CONTENTS}

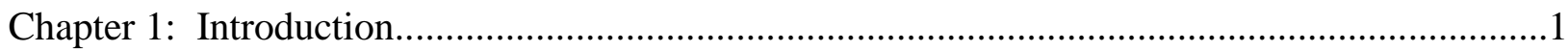

Chapter 2: The Constitution of Great Britain....................................................................... 12

Chapter 3: The Stamp Act: Causes and Consequences.........................................................20

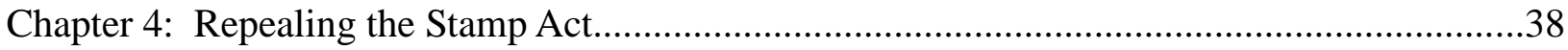

Chapter 5: Constitutional questions and reactions to the repeal of the Stamp Act....................48

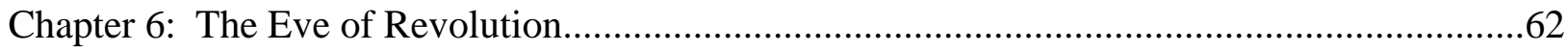

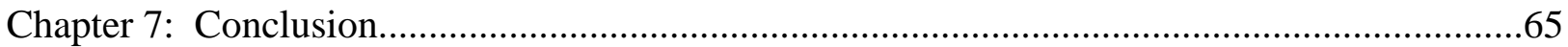

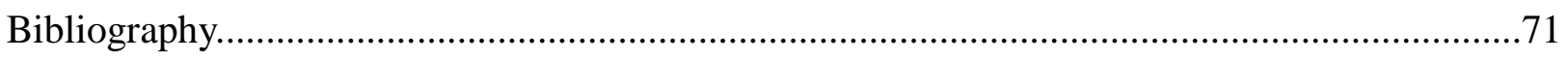




\section{Introduction}

On April 19, 1775 in Lexington, Massachusetts a detachment of the British Army, ordered by Massachusetts Governor Thomas Gage to seize a reported cache of arms in Concord, encountered a unit of armed colonists on the commons. These men were not the legendary minutemen but a relatively untrained group of commoners loosely organized by Captain John Parker, a veteran of the French and Indian War. This is where standard elementary school history steps in. The "shot heard 'round the world" was fired from an unknown source and the colonists were at war with Great Britain. ${ }^{1}$ It has become a staple in American mythology of the weak and oppressed standing up to the powerful and exploitative British Empire. It is the myth of the noble fight for freedom over tyranny which still endures today. The muddy commons of 1775 Lexington is now a grassy park complete with a statue of a minute man and a fifty-foot tall flag pole with the words "Birthplace of American Liberty" proudly displayed. However, this encounter was strategically irrelevant as the colonists were badly outnumbered and in the process of dispersing in the face of the superior British troops when the mysterious shot plunged the colonists into all-out war. The British troops continued to Concord where the better trained minutemen were able to stop the British forces and chase them back to Boston. ${ }^{2}$

Regardless of the true nature of the encounter, storytellers gravitate towards it because of its mythological nature. The simple explanation of fighting for freedom, as

1 This famous phrase is from the poem "Concord Hymn" by Ralph Waldo Emerson (1836). It is interesting to note that the shot refers to the later skirmish on the North Bridge in Concord and not the earlier encounter in Lexington.

2 The distinction of the men in Lexington as a militia and the men in Concord as minutemen is discussed in David Hackett Fischer's examination of the conflict entitled Paul Revere's Ride. 
the sign on the flagpole in Lexington seems to suggest, contains some truth in the reasons why the colonists rebelled against Great Britain. But to suggest that the American Revolution was a struggle for freedom is misleading. Rather, this was a constitutional struggle that was impossible to resolve due to a difference in the understanding of the British Constitution. The colonists in North America were resisting a change in Parliamentary policy that they believed was unconstitutional.

The colonists were not always interested in revolution, it was the increasingly aggressive acts of Parliament following the French and Indian War that drove the colonists first to resistance and then to rebellion. It was not exclusively the question of taxation without representation that caused the American Revolution, it was primarily Parliament's change in policy towards the colonists. Parliament used its political and military power to change its policy and tighten the administration of the North American colonies. In response, the colonists defended their understanding of their rights as British citizens against new taxes and an expanding administrative and military presence.

Historians have analyzed the causes and consequences of the American Revolution from an economic and political perspective, among other perspectives, for many years. Most of the arguments center around the idea of taxation without representation, the breaking point being a series of so-called "intolerable acts" in the early 1770s. Prominent works in this field include Edmund S. Morgan and Helen M. Morgan's The Stamp Act Crisis: prologue to revolution (1953), Edmund S. Morgan's The Birth of the Republic: 1763-89 (1956), Bernard Bailyn's The Ideological Origins of the American Revolution (1967), and Gordon S. Wood's The Creation of the American 
Republic, 1776-1787 (1969). These historians dealt with the ideological and constitutional questions about the origins of the American Revolution.

Jack P. Greene, however, provides an excellent examination of the constitutional questions which resulted in Great Britain losing thirteen colonies in North America. In The Constitutional Origins of the American Revolution Greene argues that the American Revolution "was the unintended consequence of a dispute about law."3 Essentially, many colonists disagreed with prominent members of Parliament over what authority Parliament had over the colonies. It was this conflict and the inability of Parliament and the colonists to arrive at a compromise that led to the American Revolution.

The continual disagreement over what was constitutional led to the "intolerable acts" which were a series of Parliamentary proclamations enacted in direct response to the Boston Tea Party of 1773 . These acts were meant to finally put an end to years of colonial resistance to Parliamentary authority. Parliament was mistaken as it was during these years that colonial resistance became galvanized, organized, and violent. In essence, the colonists did not consider themselves as outsiders under imperial rule. They identified themselves as British citizens entitled to all the rights enjoyed by their compatriots in England.

An examination of the legislation of the 1760 s and subsequent reactions will give a perspective of both Parliament's and the colonists' ideas of the meaning of the constitution. It is these ideas which explain why Parliament's change in policy toward the colonists was resisted.

3 Jack P. Green, The Constitutional Origins of the American Revolution (Cambridge: Cambridge University Press, 2011), 1. 
The origins of the contrary interpretations of the constitution can be found in England over a century prior to the American Revolution. As the colonies flourished in the seventeenth century, a political crisis was occurring in England. Concerns over royal despotism divided the kingdom and civil war erupted between the Parliamentarians, those that supported a constitutional government, and the Royalists, who supported the traditional line of succession. The result of the civil war and the subsequent Glorious Revolution of 1689 changed the nature of the government in such a way that would complicate matters with the colonists in the eighteenth century. Parliament not only gained considerable power over the king, but it also gained control over economic policies.

It was indeed an economic crisis that set in motion the chain of events leading to the American Revolution. In 1754 Great Britain and France were at war. The French and Indian War began, among other reasons, over control of the Ohio Valley. The war ended with French defeat and the Treaty of Paris in 1763. It was devastating to the British economy and all but bankrupted the royal treasury. The Prime Minister of Great Britain, George Grenville, was tasked by King George III with the economic recovery of the empire. In 1765 he proposed a series of bills in Parliament that he believed would help fill the royal treasury. Grenville believed that the colonists of North America should be held partly responsible for the cost of the French and Indian War. His argument was that the British government waged an extremely expensive war to protect the colonists and they should therefore bear a portion of the cost of the war and of the cost of maintaining a military presence in the colonies after the war. 
One of Grenville's bills became the Stamp Act of 1765. This act required that all manner of business in the colonies be printed on special paper bearing an official stamp. In essence, virtually every transaction would be assessed a tax. Many colonists quickly protested these taxes arguing that they represented an internal tax, or a tax against property, which they deemed unconstitutional because they were not represented in Parliament. These colonists made a distinction between internal and external taxes. Internal taxes were taxes levied against the colonists directly, such as the Stamp Act which taxed everyday transactions. External Taxes were indirect taxes that were not assessed on the colonists individually but on trade items. Taxes would be levied on products as they entered the colonies and the merchants would adjust costs accordingly. These colonists believed constitutionally that Parliament could legislate these external taxes because they did not directly tax their property but could not legislate internal taxes.

What is considered property was important for the arguments of these colonists. There was not one medium of exchange circulating throughout North America and Great Britain. Therefore wealth as a whole was considered property because it could take different forms. Land, silver, livestock, consumable goods, and printed currency, among other things, were considered legal tender and were also categorized as property. This is an important distinction when analyzing what a tax was targeting because property was of greater importance to the colonists than the English. Gordon S. Wood writes "the colonies had no bank of England, no stock exchange, no great centers of capital, and no 
readily available circulating medium of exchange."4 Therefore "a farmer might lend his oxen to a neighbor in return for help in harvesting his crop" or "a midwife might trade her services for wool or tobacco."5 But Wood points out that most exchanges took the form of credit where goods or services were exchanged for a monetary value that was recorded into account books. Therefore all property had value and as, Robert Middlekauff argues, property “conferred political character, or being, on a man."6 According to Middlekauff, the colonists did not yield political power through the traditional sources of ancestry or lineage so they defined their power through wealth and property. $^{7}$

It is important to note that the colonists were never united politically and can not be considered as a single group of like-minded people. There were political factions between the colonies and political factions within each colony. The source of this factionalism came from various issues including the regulation of trade, the appointment of officials, and the power of the governors versus the power of the assemblies. Middlekauff argues that despite these factions, political society remained strong. The colonists "recognized that limits existed and that exceeding them might bring the political system to collapse." ${ }^{\prime 8}$ This is significant because once the colonists were faced with a crisis from the outside, such as the Stamp Act, they effectively banded together. To be sure, there was still political factionalism throughout the crisis, but the unity

4 Gordon S. Brown, The Radicalism of the American Revolution (New York: Vintage Books, 1993) 65.

5 Brown, 67.

6 Robert Middlekauff, The Glorious Cause: The American Revolution, 1763-1789 (Oxford: Oxford University Press, 2005), 123.

7 Ibid, 124.

8 Ibid, 45. 
created by the crisis was strong enough to endure the challenges they encountered.

Faced with protests from the colonies and great difficulty in enforcing the Stamp Act Parliament held a debate over the legality of the act. In the end they voted to repeal the Stamp Act, not because they agreed with the colonists' arguments, but because it became clear that enforcing the act would be impossible. This nuance was lost on the colonists and they celebrated a great victory over Parliament. Immediately following the repeal of the Stamp Act Parliament passed another act that went relatively unnoticed by the colonists. In 1767 Parliament passed the Declaratory Act which asserted supreme authority over the colonists of North America "in all cases whatsoever." Complicating the issue was the nature of the British constitution and the idea of precedence in EarlyModern Britain. The British constitution was not an organized document but instead a collection of all the acts and proclamations passed by monarchs and Parliament since the creation of the Magna Carta in 1215. Therefore interpretation of British constitutionalism varied greatly as the debate on the Stamp Act will show.

As mentioned earlier, the civil wars and the Glorious Revolution of the seventeenth century changed the nature of British constitutionalism. The passage of the Bill of Rights in 1689 and how they were derived from the Magna Carta was source material for the colonists' case against Parliament as well as Parliament's rebuttal. As Jack P. Greene argued, precedence, defined as custom and usage, was very important to the British and was the means by which both Parliament and the colonists argued their cases. ${ }^{9}$ Therefore Parliament simply passed a proclamation stating that they had supreme authority over the colonies. While there was an intense debate before the act was passed,

9 Green, 24. 
there was a precedent. In 1720, Parliament passed a similar act in Ireland in which it was proclaimed "that the said kingdom of Ireland hath been, is, and of right ought to be subordinate unto and dependent upon the imperial crown of Great Britain." ${ }^{10}$ Indeed, Parliament had no reason to believe they could not pass any act they deemed appropriate concerning the colonists. There had always been a sense of subordination with the colonies that was rarely called into question. The problem was that many members of Parliament did not believe there was a limit to that relationship, while in the colonies, there were those that believed there was. According to Middlekauff "there were distinct limits to these colonial attitudes, and with the crisis produced by the Stamp Act, Parliament, and the Grenville ministry had blundered across those limits."11

Historians have had different ideas about why there was little colonial opposition to the Declaratory Act. Edward Countryman believes that the colonists understood the gravity of the act but sincerely hoped that Parliament would not exercise its power. ${ }^{12}$ Gordon S. Wood argues that the colonists believed they could convince Parliament, despite the passage of the Declaratory Act, that they were able to efficiently govern themselves. Furthermore, Wood supposes the colonists had given up "trying to divide what royal officials told them could not be divided."13 Edmund S. Morgan explains that Richard Jackson, Massachusetts' agent in London, encouraged the colony not to worry about the act because Ireland had not been taxed since the passage of the similar statute

10 The Statutes at Large of England and of Great Britain: From Magna Carta to the Union of the Kingdoms of Great Britain and Ireland (1811), vol. 4, p. 481.

11 MiddleKauff, 145.

12 Edward Countryman, The American Revolution, (Hill and Wang, 2003), 49.

13 Gordon S. Wood, The American Revolution: A History. (New York: Modern Library, 2003) 44. 
of $1720 .{ }^{14}$ Morgan writes "thus the fact, so often remarked by historians, that the colonists took little notice of the Declaratory Act, does not mean that the colonists were indifferent to the question of principle. They could acquiesce in it with a clear conscience and without inconsistency, unaware that their interpretation differed radically from that held in Parliament."15 If Morgan's conclusion is viable then it would seem that the Townshend Acts of 1767, which held the colonies responsible for the cost of maintaining the British army in North America, would have led to greater protest. There were some isolated responses to the Townshend Acts but nothing compared to what was seen during the Stamp Act crisis and what would occur with the "intolerable acts" in 1774.

The reason why the colonists waited as long as they did to rebel against Great Britain is threefold. First, as Countryman and Morgan suggest, the colonists believed, based on Great Britain's history with Ireland, that Parliament would not have the need to exercise the power of the Declaratory Act. Secondly, the subsequent acts did not create the same level of protest and opposition as did the Stamp Act. Thirdly, it was only when Parliament severely punished Boston with the "intolerable acts" that the other colonies understood the gravity of the British attitude towards the colonies coupled with the power of the declaratory act. This attitude seemed to have gone beyond the question of the constitutionality of the taxation of the colonists. Indeed, it can be argued that Parliament's reaction towards the colonists in the 1770s, which led to the American Revolution, was an attempt demonstrate that authority over the colonies did indeed rest

14 Edmund S. Morgan, "Colonial Ideas of Parliamentary Power, 1764-1766," The William and Mary Quarterly, Third Series, Vol. 5, No. 3 (July, 1948), 329.

15 Ibid, 330. 
with them.

The ideas over Parliamentary rights that were argued during the 1770 s were similar to the arguments used during the Stamp Act Crisis. It will be useful to trace the evolution of these arguments in a few different ways. First, there needs to be an examination of the transition of power from the monarchy to Parliament during the seventeenth century by examining the Magna Carta, the Bill of Rights of 1689, and Parliament's record during the early eighteenth century. It is here where Parliament traces its authority and where the colonists trace their right to representation.

Once these questions are answered, it will be important to examine the reaction of both the members of Parliament and the colonists after the repeal of the Stamp Act. Using Parliamentary records and colonial opinions expressed through pamphlets, letters, and newspaper publications we will get a sense of the general attitude of the members of Parliament and the colonists. We will also see how the colonists held a degree of faith in Parliament to make the correct constitutional decisions despite the change in Parliament's policies. It is clear that open rebellion was not what the colonists preferred in the years following the repeal of the Stamp Act. This process will show that the colonists believed with a strong degree of certainty that Parliament had limits in its authority over the colonists while at the same time Parliament believed they had complete authority over the colonies.

This is strictly a political history. It will be primarily based on the legal arguments on both sides of the issue. Because the question deals with why the colonists did not act, or more accurately delayed action, suppositions are inevitable. The question, 
however, is an important one to ask. Many of the recent articles and manuscripts on the American Revolution deal with radicalism, social ideologies, nationalism, economics, and other categories. ${ }^{16}$ These theories are undoubtedly important in creating an over-all picture of what the American Revolution embodied. However, the fact remains that the colonists had no interest in splitting from Great Britain. Even the most "radical" of the revolutionaries of the 1770s were loyal British subjects in 1766 and had no desire to abandon their motherland.

The process was relatively slow and the peripheral ideas of nationalism and radicalism developed as the colonists became increasingly frustrated with the changes in policy from Parliament. Indeed, historians such as Greene, Middlekauff, Morgan, and Wood agree that the colonists were fighting to preserve a British way of life. Therefore it is important to look for the roots of revolution through the political machinations between 1766 and 1770. As stated, the careful examination of what legislation Parliament passed, and more importantly why it was passed, and how and why the colonists resisted them will show that the colonists merely wanted to enjoy the same rights that were afforded to their compatriots in England and more specifically, they wanted a voice in the decisions regarding their property. More importantly, it was the disagreement between Parliament and many colonists over the constitutionality of Parliament's change in policy towards the colonies that ultimately led to revolution.

16 Gwenda Morgan provides an excellent summary of the historiography in The Debate on the American Revolution which highlights the predominant work in the fields of ideology, radicalism, gender issues, cultural issues, and African and Native American issues. Morgan, Gwenda. The Debate on the American Revolution, (Manchester: Manchester University Press), 2007. 


\section{The Constitution of Great Britain}

The concept of the constitutional monarchy as it was considered in the eighteenth century is a complicated issue. It is for this reason that the change in policy by Parliament after the French and Indian War created great controversy in the colonies. Beginning with the Magna Carta, which was first issued in 1215 and amended several times until the final version was issued in 1297, England and later Great Britain experienced several critical periods in which the question of the monarch's power was considered. A brief summary of the events that shaped the British government in the eighteenth century will help in analyzing the ways in which the colonists and Parliament disagreed about the nature of the Constitution.

The Magna Carta attempted to set forth limits to the monarch's power while simultaneously defining a set of rights for freemen. In practice it can be generally argued that the document had little effect on royal authority until the seventeenth century. The War of the Roses in the fifteenth century proved that factional warfare and the power of "over-mighty subjects" trumped any of the rights set forth by the Magna Carta. In the sixteenth century Henry VIII forged what has been described as a despotic reign. ${ }^{17}$ While the debate continues over whether his reign was truly despotic, it is clear that Henry VIII used his influence over Parliament to solidify his power. The Civil Wars and the Glorious Revolution of the seventeenth century all but settled the question of monarchical power when Parliament secured power over legislation and taxation and

17 For more information, see Joel Hurstfield's article "Was There a Tudor Despotism After All?" Transactions of the Royal Historical Society (Fifth Series) (1967), 17: 83-108 Cambridge University Press. 
created the constitutional monarchy that essentially existed in the eighteenth century. The Glorious Revolution culminated in the Bill of Rights of 1689.

Beginning with the Magna Carta, there are several issues that helped define the role of Parliament and the rights of the subjects that were addressed in the events leading to the American Revolution. The first issue relates to rights of the the subjects outlined in the Magna Carta:

No freeman is to be taken or imprisoned or disseised of his free tenement or of his liberties or free customs, or outlawed or exiled or in any way ruined, nor will we go against such a man or send against him save by lawful judgment of his peers or by the law of the land. ${ }^{18}$

There are two main points to be taken from this passage. First, it states that no one will be "disseised" or separated from his tenement, or property. This is an important distinction as property in the eighteenth century was also considered wealth. Because trade was conducted both with currency and trade in kind, direct taxation was considered by the colonists as the confiscation of property. The second point about this passage concerns the phrase "save by lawful judgment of his peers or by the law of the land." This phrase served the arguments of both Parliament and the colonists. Parliament argued that they are the law of the land and can therefore impose any tax they deemed appropriate. The colonists on the other hand argued that since they were not represented

18 Yale Law School, “Avalon Project: Documents in Law, History, and Diplomacy," Lillian Goldman Law Library, Http://avalon.law.yale.edu/medieval/magframe.asp 
in Parliament there could not be any judgment by their peers. This will be addressed in greater detail below.

The Magna Carta is simply the very first source used in the debate over Parliament's power. The nature of the English Constitution after the civil wars and the Glorious Revolution of the seventeenth century created a disagreement between Parliament and the colonists over the extent of Parliament's authority. The arguments used during the civil wars and the Glorious Revolution is relevant to this subject. Prior to these events, Parliament was not a permanent institution. It was summoned only at the request of the monarch for the purpose of gaining approval to raise funds. Additionally, once summoned, the Parliament could petition the monarch. The reign of Charles I from 1625 until 1649 was troublesome to the members of Parliament for several reasons. Charles I believed in the sanctity of the monarchy and resisted Parliament's insistence that the monarch needed their approval for taxation. When Parliament denied any of Charles I's requests he was quick to dissolve the. As a result of these dissolutions, Charles I raised funds through the crown, which many members of Parliament believed to be illegal. These events, among many other complex issues, caused great tension between Charles I and Parliament and eventually led to civil war between the Royalists, who supported the king, and the Patriots, who supported Parliament. However, the arguments leading up to the civil war help to explain the complexities of English law and why, in the eighteenth century, these same arguments existed.

The Magna Carta was influential in the seventeenth century as England moved towards a constitutional government. After the Magna Carta was written, Parliament 
passed laws and statutes to help further define governmental procedures. Acts and statutes were constantly revised, removed, and replaced throughout the years. The Magna Carta, therefore, was source material by which decisions were made but it was Parliament, often with royal influence, that determined if a given statute was constitutional. This posed the question: Did Parliament decide the law of the land or was it merely a ratifying body at the whim of the monarch? History suggests that, in practice, the latter was true. Charles I was more or less forced to call Parliament several times in his reign. He continually faced opposition over his tax policies, religious inclinations, and appointments. These issues and Charles I's frequent dismissal of Parliament raised the question of what Parliament's role was and ought to be.

This led to the English Civil War which lasted from 1641 until 1651. The Royalist army commanded by Charles I fought against the army of Parliament. Charles I and his supporters believed in the absolute sovereignty of the crown. Other, more modern, arguments began to surface during this time. The general argument was that laws could not be made or enforced without the consent of the subjects. The House of Commons was the representative of the subjects in Parliament and therefore Parliament, not the crown or the courts had the power to legislate new laws. Ironically, it was the despotic acts of Henry VIII that were cited as the source of Parliament's power. Henry VIII wanted absolute power but at the same time wanted it to appear legitimate. As G. R. Elton writes

Thus the political events and constitutional expansion of the 1530 's produced major changes in the position of Parliament. Long and frequent 
sessions, fundamental and far-reaching measures, revolutionary consequences, governmental leadership - all these combined with the Crown's devotion to statute and use of Parliament to give that institution a new air, even to change it essentially into it's modern form as the supreme and sovereign legislator. ${ }^{19}$

Therefore the prevailing belief among the Parliamentarians in the first half of the seventeenth century, was that only Parliament had the power to legislate and enforce laws. That power, however, was derived at the consent of the subjects, who were represented in the House of Commons. ${ }^{20}$

After the execution of Charles I in 1649, England became a commonwealth for a short time under Oliver Cromwell and, after his death, his son Richard. Richard was removed from power and the exiled Charles II was restored to the throne. After his death James II became king. His belief in the absolute divine right of kings and his Catholic agenda prompted prominent protestants to request the aid of William of Orange who was married to James II's daughter Mary. During the Glorious Revolution, William invaded England and James II fled. In 1689 William became King William II. Shortly thereafter, Parliament passed the Bill of Rights limiting the power of the sovereign and establishing Parliament as the supreme legislative body of the government. It is the Glorious Revolution and the subsequent passage of the Bill of Rights that effectively transformed British government into a constitutional monarchy.

19 The Tudor Constitution, edited and introduced by G.R. Elton (Cambridge, 1960), p. 234.

20 J. P. Sommerville, Royalists and Patriots: Politics and Ideology in England 1603-1640, (Addison Wesley Longman, New York, 1999) p. 92. 
The Bill of Rights begins by listing the several abuses of power that were committed by James II according to Parliament. ${ }^{21}$ These included subverting the protestant faith, passing laws without Parliament's consent, collecting revenue without Parliament's consent, keeping a standing army in a time of peace without Parliament's consent, and prosecuting and sentencing subjects without due process. The Bill of Rights then corrects these issues by making them illegal without the consent of Parliament. The sovereign was no longer able to issue or remove laws independently, the levying of taxes could only occur through Parliament, and the election of members of Parliament were made free. Because the levying of taxes and the creation of armies was bound to Parliamentary consent, the sovereign was bound to Parliament. To be sure, the monarch still possessed great power but it was reliant on consent from parliament. The Bill of Rights also reaffirmed the right of representation for English subjects.

A couple of subsequent events are important to mention. In 1707 Scotland's Parliament was united with England's Parliament in which forty-five members were added to the House of Commons. The House of Commons represented the subjects through the election of representatives. This created a precedence in which the addition of new subjects were given representation in Parliament.

In 1720 Parliament passed the Irish Declaratory Act which stated that in Ireland:

21 Yale Law School, “Avalon Project: Documents in Law, History, and Diplomacy,” Lillian Goldman Law Library, Http://avalon.law.yale.edu/17th_century/england.asp. 
The king's majesty, by and with the advice and consent of the lords spiritual and temporal, and commons of Great Britain in Parliament assembled, had, hath, and of right ought to have full power and authority to make laws and statutes of sufficient force and validity to bind the kingdom and people of Ireland..$^{22}$

The Irish never accepted the act but did little to combat it. Perhaps the most vocal of the Irish opponents to British policy was Jonathan Swift, the poet and satirist most known for "Gulliver's Travels." Swift's writings usually condemned Britain's economic policies towards Ireland arguing that the policies subjected Ireland into poverty. This is significant because it shows that the idea of legislating supreme authority was not new to Parliament in 1760s. It also shows that Parliament did not always enforce the laws that they passed.

The events that shaped British politics in the decades and centuries prior to the American Revolution clearly show that the constitution was a complicated entity subject to varying interpretations. Once Parliament secured much of the monarch's power it is clear that they would interpret the constitution in such a way that would legitimize the policies they thought were for the benefit and prosperity of the kingdom and empire. Lastly, the nature of the constitution is important because its interpretation was central to the arguments of both Parliament and the colonists when Parliament changed its policy towards the

22 The Statutes at Large of England and of Great Britain: From Magna Carta to the Union of the Kingdoms of Great Britain and Ireland (1811), vol. 4, p. 481. 
colonies. It is this difference in interpretation that would ultimately lead to revolution. 


\section{The Stamp Act: Causes and Consequences}

The origins of the change in Parliament's policy toward the colonists can be found during the French and Indian War which was fought from 1754 and 1763. The war was a true world war involving most of the great powers of Europe and fought throughout the colonies of the world as well as Europe. Although the British were victorious, the war left the empire nearly bankrupt. In an effort to alleviate the dire economic situation at home, Parliament decided to tax the colonists. The justification made by Parliament was that the war in North America cost Great Britain both economically and in lives. Therefore, Parliament believed the colonists needed to bear their share of the cost of the war because it was the government and army of Great Britain that ultimately protected the colonists from French aggression. Regardless of the validity of this argument, and some colonists did not agree that they needed to be protected, the colonists were more concerned that Parliament was changing the way they legislated in relation to the colonies.

It was not the tax itself that concerned the colonists, it was the source of the tax. Edmund S. Morgan describes it best when he writes:

"For Americans the great thing about this empire, apart from the sheer pride of belonging to it, was that it left you alone. The average colonist might go 
through the year, might even go through a lifetime, without seeing an officer of the empire."23

This is not to say the colonists were completely unfamiliar with British regulations on commerce as there were a series of acts passed by Parliament over the years known as the navigation acts which did not tax the colonists directly but ensured that most of the trade stayed within the empire. Morgan argues that the reason these apparent limitations did not raise alarms was due to the strength of the empire. While there was some competition with foreign markets, the trade between the East India Company, the colonists, and England proved to be the most lucrative. ${ }^{24}$ There was one act passed in 1733 that might have prompted protest from the colonists. Parliament placed a tax on molasses which would have destroyed the lucrative rum trade. However, Great Britain did not enforce the act as the few men they employed to collect the tax were easily bribed. ${ }^{25}$

The situation that existed prior to 1763 was that of an empire that was able to prosper while allowing the colonies to essentially govern themselves. As Jack P. Greene explains, the colonists' right to govern themselves "had thus subsequently been 'sanctified by successive usage, grounded upon a generous reliance on English Faith and Compact, and that usage (was) ratified by repeated authoritative acquiescence" by the crown and Parliament. ${ }^{26}$ After the French and

23 Edward S. Morgan, The Birth of the Republic:1763-1789 (Chicago: University of Chicago Press, 1992), 9. 24 Morgan, 10.

25 Ibid, 11.

26 Greene, 75. 
Indian War, however, Great Britain was in the midst of an economic emergency and raising taxes on the subjects living in the British Isles would not be enough to alleviate the problem. Parliament felt they had no choice but to tap into the vast resources of the colonists through taxation. What followed was a series of political decisions by Parliament each of which further alienated the colonists from the empire.

The first act of Parliament after the conclusion of the French and Indian War was the Proclamation of 1763 . This act recognized the territorial acquisitions from the French and Spanish at the conclusion of the war. Quebec, West Florida, and East Florida were made official colonies of the crown. Furthermore, all acquired lands that were not within the boundaries of an official colony were placed under the protection of the crown but off limits to settlement. Lastly, forts and troops were to be placed along the border to prevent Native Americans from entering the colonies and to prevent the colonists from leaving the colonies. $^{27}$

According to Morgan, Parliament planned on sending ten thousand British troops to the region to secure the frontier. The thought of what would be required to support such a force was the first indication to the colonists that there may be trouble from Parliament. ${ }^{28}$ In essence, the colonists not only disagreed with the source of the tax, but the reason for it seemed dubious as well.

27 Yale Law School, “Avalon Project: Documents in Law, History, and Diplomacy,” Lillian Goldman Law Library, Http://avalon.law.yale.edu/18th_century/proc1763.asp.

28 Morgan, 15. 
It was not long before the colonists discovered how Parliament planned to reduce Great Britain's war debts and pay for the standing force in the frontier. In 1763, Chancellor of the Exchequer George Grenville submitted a new version of the Molasses Act of 1733 which reduced the tax on rum products in an effort to eliminate the practice of bribing the tax collectors. Grenville also added language to the act requiring specific paperwork be filed for all cargo entering and leaving the colonies. Lastly, all violations of the act would be tried in the Admiralty Courts instead of the local courts in the colonies. In essence, the new Sugar Act did not do anything to increase the price the colonists paid for the products, it was merely redirecting the money that would normally be used for bribes to the crown. There was a phrase in the act, however, that alerted the colonists as to Parliament's true motive and was a warning that the Sugar Act was not the only measure Parliament would implement. The act stated that one of the purposes was to collect money "towards defraying the Expenses of defending, protecting, and securing, the said Colonies and Plantations." 29 The phrase "towards defraying the expenses" is vague and does not specifically state what amount would be sufficient. The colonists had no way of knowing when the said costs were sufficiently defrayed.

Parliament passed another act in 1764 entitled the Currency Act. This act required that the colonies use official currency based on the pound sterling in all transactions. As stated previously the colonies adopted many different modes of

29 Yale Law School, “Avalon Project: Documents in Law, History, and Diplomacy,” Lillian Goldman Law Library, Http://avalon.law.yale.edu/18th_century/sugar_act_1764.asp. 
exchange. As well as using official British currency, some transactions were conducted through trade in kind. There were also various forms of credit that were essential to the colonial economy and some colonies even printed their own currency. To be sure, there was not a great deal of actual currency circulating through the colonies so credit and trade were sometimes the only way to conduct any transactions at all. Parliament felt that this was too complicated a system and impossible to regulate. The Currency Act sought to remedy these problems by making the pound sterling the only valid currency in the colonies. It rendered all currencies printed prior to the act invalid and outlawed the the further printing of currency. ${ }^{30}$

The consequence of the act was more psychological in nature. At first the colonists feared that it would ruin their economy. Those that had massed large amounts of currency printed within the colonies feared they had lost their fortunes. Others thought that trade would be stifled due to the lack of valid currency circulating in the colonies. These fears were never realized as enforcement of the act was not overly effective. Trade continued in much the same way as it had prior to the act. However, the act did manage to give the colonists another example of how Parliament was changing its policy towards the colonists. $^{31}$ In a little over eighteen months since the end of the French and Indian War the colonists were removed from certain regions of the frontier, troops were

30 Yale Law School, “Avalon Project: Documents in Law, History, and Diplomacy,” Lillian Goldman Law Library, Http://avalon.law.yale.edu/18th_century/currency_act_1764.asp.

31 For an in-depth analysis of the Currency Act and its effect on the colonies, see "The Currency Act of 1764 in Imperial-Colonial Relations, 1764-1776” by Jack P. Greene and Richard M. Jellison. 
sent to secure the western border, and the colonists discovered that Parliament was beginning to hold them responsible for the cost of military activity in North America. While there was some protest to the Sugar Act, the Currency Act, and the taxation of the colonists in general, the colonies remained quiet on this issue. $^{32}$ It only took another year before Parliament's policy of introducing new taxes in the colonies caused significant resistance.

George Grenville was not content with the Sugar Act and was already planning another proposal while the act was being debated in Parliament. At this time in Great Britain there existed a stamp duty which was enacted in 1694 to help defray the costs of a previous war with France. Essentially, any transaction that required the use of parchment required an official stamp. Royal officials collected the tax before affixing the stamp on the document. Grenville stated that since the tax was now an institution in Great Britain, it only made sense that the colonists should be subject to it as well. Grenville was concerned that the authority of Parliament would be undermined if taxation was "not extended to all the members of the state, in proportion to their respective abilities." 33 Parliament added identical language to this new Stamp Act that was found in the Sugar Act which immediately alarmed the colonists. The Sugar Act reads that it was necessary in "defraying the expenses of defending, protecting, and securing the British colonies and plantations in America" and the Stamp Act was necessary for "raising a further revenue within your majesty's dominions in America toward

32 Morgan, 15. Regarding the taxation of the colonists, Sir Roger Walpole (1676-1745) is thought to have said: "I will leave that for some of my successors, who may have more courage than I have."

33 Cobett's Parliamentary History, Volume 16, (Oxford Digital Library), 204. 
defraying the said expenses. ${ }^{34}$ Parliament was trying to both recover the costs of the French and Indian War and cover future expenses that might be incurred by the administration of the colonies.

Two issues might have concerned the colonists with the Stamp Act. First, the question of the colonists needing protection from the British Army might have raised some colonial eyebrows. For instance, Benjamin Franklin stated in Parliament that before the French and Indian War the colonists were "before in perfect peace with both French and Indians" and that British troops were not sent for the purpose of defending the colonists because the war "began about the limits between Canada and Nova Scotia." 35 Franklin did not believe the colonists needed protection. Second, the Stamp Act might have alarmed the colonists because of the phrase "raising further revenue." Since the colonists had no representative in Parliament they had no way of knowing what amount of revenue was required to successfully defray these expenses and so it appeared Parliament now had a way to indefinitely pass tax after tax against the colonists.

The colonists believed that it was necessary to oppose the Stamp Act but they did not know to what extent and by what means they should do so. In a letter published in many newspapers, the author stated:

"We knew not what to say or write (regarding the Stamp Act), even our presses almost ceased to utter the language of liberty. At last, by degrees we

34 Yale Law School, “Avalon Project: Documents in Law, History, and Diplomacy,” Lillian Goldman Law Library, Http://avalon.law.yale.edu/18th_century/stamp_act_1765.asp.

35 Cobett's Parliamentary History, 154. 
began to recollect our scattered thoughts. As soon as the latent sparks of patriotism began to kindle, it flew like lightning from breast to breast."36

In the July 18, 1776 edition of The Virginia Gazzette one commentator explained "it was the authority that imposed the tax, and not the tax itself, which the Americans were opposed to."37

Before the Stamp Act was enacted, Massachusetts and Virginia filed petitions to Parliament in opposition to the Sugar Act and the proposed Stamp Act. The Massachusetts petition addressed two important issues regarding the Sugar Act. On Parliament's authority over the colonists the petition states "that every Act of Parliament, which in this respect distinguishes his Majesty's subjects in the colonies from their fellow subjects in Great Britain, must create a very sensible concern and grief," meaning that passing legislation specifically targeted only at the colonists was unconstitutional. The petition also explained that trade had suffered greatly since the end of the French and Indian War and the colonists were not in a position to pay the taxes proposed by the Stamp Act. Arguing that such taxes are unconstitutional until the colonists are represented in Parliament, the petition requested "that the privileges of the colonies relative to their internal taxes which they have so long enjoyed, may still be referred, until your petitioners, in conjunction with the other governments, can have opportunity to make a more full representation of the state and the condition of the colonies and

36 The New-Hampshire Gazette and Historical Chronicle, November 22, 1765.

37 The Virginia Gazette, July 18, 1766, accessed December 22, 2010, http://research.history.org/DigitalLibrary/VirginiaGazette/VGIssueThumbs.cfm?IssueIDNo=66.PD.22 
the interest of Great Britain with regard to them." In other words, they either wanted to raise taxes through their own assemblies or somehow secure representation in the Parliament. ${ }^{38}$

Colonial representation in Parliament was not a serious option. Daniel Dulany, a politician from Maryland argued that it was impossible to have colonial representation in Parliament because the representatives must be "inseparably connected in their interests" and their constituencies. Dulany concludes "there is not that intimate and inseparable relation between the electors of Great Britain and the inhabitants of the colonies, which must inevitably involve both in the same taxation." According to Dulany, Parliament did not have the right to directly tax the colonists because colonial representation rested within the local assemblies. $^{39}$

The petition sent by the Virginia House of Burgesses in December of 1764 was more acerbic than that of Massachusetts. After stating that the proposed Stamp Act "ought not to be made without the consent of representatives chosen by themselves" they cited a precedent in which the Parliament under King Charles II wanted to propose a tax on Virginia and did so by sending the proposal to the Governor of Virginia who then sent it to the General Assembly for approval and implementation. The petition is therefore arguing that, through usage and custom, the British government has approved of the General Assembly as a body that can levy taxes. Lastly, the petition states:

38 Yale Law School, “Avalon Project: Documents in Law, History, and Diplomacy,” Lillian Goldman Law Library, Http://avalon.law.yale.edu/18th_century/petition_mass_1764.asp.

39 Daniel Dulany, Considerations on the Propriety of Imposing Taxes in the British Colonies (1765). 
"British patriots will never consent to the exercise of anticonstitutional power, which even in this remote corner may be dangerous in its example to the interior parts of the British Empire, and will certainly be detrimental to its commerce." 40

Thomas Whatley, who was charged by Grenville to draft the Stamp Act legislation, tried to gauge the colonial reaction to the Stamp Act. Whatley wrote Jared Ingersoll, an acquaintance living in Connecticut asking his opinion on any possible reaction of the colonists to the Stamp Act. Ingersoll responded by stating that the colonists would heavily oppose any act which would seem contrary to their constitutional rights as Englishmen and that the proposed Stamp Act, a tax without the consent of the colonists, would be seen as unconstitutional. ${ }^{41}$ According to Robert Middlekauff, obvious signs of opposition were ignored by Whately. This was either due to Whately's ignorance of colonial politics or simply because he knew Grenville would not tolerate arguments about Parliament's right to tax the colonies. ${ }^{42}$ Because Whatley's information was not made known to Parliament and the petitions made by the colonies were not officially entered into the record, the Stamp Act easily passed in both houses of Parliament. In the New-Hampshire Gazette and Historical Chronicle the event was likened to the funeral march of liberty but with hope. The skies were

40 Yale Law School, “Avalon Project: Documents in Law, History, and Diplomacy,” Lillian Goldman Law Library, Http://avalon.law.yale.edu/18th_century/petition_va_1764.asp.

41 Middlekauff, 77.

42 Ibid, 76. 
overcast and the populace was beset with melancholy as they asked where liberty had gone. Then a groan was heard "as if coming from the coffin! And upon closer attention, it proved to be a trance, for Old Freedom was not dead, the goddess Britannia had ordered a guardian angel to snatch Old Freedom from the jaws of frozen death." ${ }^{43}$ While the Stamp Act was considered as an assault on freedom, rumors that it may be repealed restored faith in the government.

There was immediate response from the colonies. Patrick Henry authored the "Virginia Resolves" in the House of Burgesses which declared that the inhabitants of Virginia held all of the rights and privileges as their counter parts in Great Britain and that their local assemblies, not Parliament, held the exclusive power of taxation. ${ }^{44}$

A resolution passed by the Connecticut Assembly stated that "every tax imposed on an English subject without consent is against the natural rights and the bounds prescribed by the English constitution," and "that the Stamp Act in special, is a tax imposed on the colonies without their consent." The resolution then urged the officers to execute their duties based on the common sense of the constitution and not on the illegal measures passed by Parliament. It also urged that no one should publicly call for "quiet obedience" to the illegal acts. ${ }^{45}$

The Pennsylvania Assembly adopted a resolution which proclaimed the colony had always approved of taxes when the crown or Parliament have

43 New-Hampshire Gazette and Historical Chronicle, November 15, 1765.

44 "The Virginia Stamp Act Resolution," 1765. Acessed at Http://www.ushistory.org/declaration/related/vsa65.htm

45 Yale Law School, “Avalon Project: Documents in Law, History, and Diplomacy," Lillian Goldman Law Library, Http://avalon.law.yale.edu/18th_century/ct_resolutions_1765.asp. 
petitioned for them and the colony would continually do so as long as it is done in a constitutional way. The resolution continued by asserting the equal rights of the colonists as those in Great Britain and that they could not be taxed except by their consent through representation. That representation, the resolution states, is through the Pennsylvania Assembly and therefore new taxes can only be levied by them. The document does not explicitly call for the repeal of the acts but states that their existence "must of necessity be attended with the most fatal consequences, not only to this province, but to the trade of our Mother Country." 46

An informal continental congress known as the Stamp Act Congress submitted a list of resolutions asserting their rights as subjects of Great Britain. It reasserts that among these rights is that taxation without consent is unconstitutional. The Sugar Act and the Stamp Act were therefore "subverting the rights and liberties of the colonists." It further asserts that any enforcement of the acts would greatly stifle trade between Great Britain and the colonies resulting in a net loss of income to the crown. ${ }^{47}$

Colonial merchants were also quick to react to the Stamp Act. In New York, the merchants drafted an agreement of non-importation from Great Britain. It states: "We, the underwritten, retailers of goods, do hereby promise and oblige ourselves not to buy any goods, wares, or merchandise of any person or persons

46 Yale Law School, “Avalon Project: Documents in Law, History, and Diplomacy,” Lillian Goldman Law Library, Http://avalon.law.yale.edu/18th_century/penn_assembly_1765.asp.

47 Yale Law School, “Avalon Project: Documents in Law, History, and Diplomacy," Lillian Goldman Law Library, Http://avalon.law.yale.edu/18th_century/resolu65.asp. 
whatsoever that shall be shipped from Great Britain after the first day of January next unless the Stamp Act shall be repealed."48 The Connecticut Courant reported on September 30, 1765 that many presses in the colonies considered printing monthly magazines instead of daily newspapers to avoid the Stamp Tax but decided against it because it was determined it would not have any substantial affect in helping to repeal the Stamp Act. ${ }^{49}$

John Adams held strong opinions about the Stamp Act stating that the act, "fabricated by the British Parliament, for battering down all the Rights and Liberties of America . . . has raised a Spirit that will be recorded to our Honour" and that "the People, even to the lowest Ranks, have become more attentive to their Liberties and more determined to defend them" and if the Stamp Act is established "the Ruin of America will become inevitable."50

Aside from the political and professional responses to the Stamp Act, there was plenty of opposition on the streets. Some businesses, such as a group of lawyers in New Jersey, temporarily shut down their businesses. ${ }^{51}$ Boston quickly became the center of opposition as mobs pillaged the house of one of the official stamp distributors. They also hung and burned an effigy of the stamp distributor. Civil unrest spread throughout the colonies. In North Carolina a

48 Yale Law School, “Avalon Project: Documents in Law, History, and Diplomacy,” Lillian Goldman Law Library, Http://avalon.law.yale.edu/18th_century/newyork_non_importation_1765.asp.

49 Connecticut Courant. September 30, 1765.

50 From the Adams Family Papers Digital Archive accessed at $\mathrm{Http}: / / \mathrm{www} / \mathrm{masshist.org} /$ digitaladams/aea/cfm/doc.cfm?id=D11\&numrecs=2\&archive=all\&hi=\&qyery $=1765 \% 20$ WEDNESDAY\&queryid=rec $1 \&$ start $=1 \&$ tag=text\#firstmatch.

51 The Virginia Gazette, March 7, 1766, accessed on December 12, 2010, http://research.history.org/DigitalLibrary/VirginiaGazette/VGIssueThumbs.cfm?IssueIDNo=66.PD.02 
group of protesters rafted out to a ship holding the stamps and a stamp distributor intent on setting the ship on fire. ${ }^{52}$

The colonists surely knew the dire consequences of their actions. One "gentleman in high office in America" warned that the only way to enforce the stamp act was to have the military collect the taxes. ${ }^{53}$ Edmund S. Morgan argues the Americans "knew that the full weight of the British Army and Navy might soon descend upon them, but they were ready to fight rather than submit" and formed associations across the colonies intent on resisting the Stamp Act. ${ }^{54}$ One such association was created when several sloops in North Carolina were seized after they were unable to use stamped paper for their documents because the stamps were not available in Brunswick. After several letters to the customs collector appealing the seizure of the vehicles were denied, a group of local merchants stated that they would "unite, and truly and faithfully assist each other in preventing entirely the operation of the Stamp Act."55

A number of citizens of Westmoreland County, Virginia published what has become known as the Leedstown Resolves which were published in The Virginia Gazette on May 16, 1766. These resolves asserted the belief that the Stamp Act was unconstitutional and that the signers would "exert every faculty, to

52 The Virginia Gazette, March 7, 1766, accessed on December 12, 2010, http://research.history.org/DigitalLibrary/VirginiaGazette/VGIssueThumbs.cfm?IssueIDNo=66.PD.02 53 The Virginia Gazette, March 7, 1766, accessed on December 12, 2010, http://research.history.org/DigitalLibrary/VirginiaGazette/VGIssueThumbs.cfm?IssueIDNo=66.PD.02 54 Morgan, 23.

55 The Virginia Gazette, March 21, 1766, accessed on December 12, 2010, http://research.history.org/DigitalLibrary/VirginiaGazette/VGImagePopup.cfm?ID=1490\&Res=HI 
prevent the execution of the said Stamp Act in any instance whatsoever within this colony."

These popular demonstrations were not necessarily over the right of the colonists to govern themselves. But the same ideas were important to these people on a personal level. Furthermore, these demonstrations helped to frustrate imperial rule. As Peter Linebaugh and Marcus Rediker argue "operations on sea and land, from mutiny to insurrection, made the motley crew the driving force of a revolutionary crisis in the 1760 s and the 1770 s. Such action help to destabilize imperial civil society and pushed America toward the world's first modern colonial war for liberation. ${ }^{, 57}$ In the 1766 session of Parliament, letters were entered into the record that showed a variety of opinions from both Great Britain and the colonies regarding the violence and opposition associated with the Stamp Act. There were a series of letters sent and received by King George III's Privy Councilor, Francis Seymour-Conway, which help describe the king's position regarding the colonists. In a letter to Lieutenant Governor Fauquier of Virginia on September 14, 1765, Conway makes assurances that the king viewed both the colonists and the subjects in Great Britain as equal under the constitution. He writes that the recent disturbances in the colonies have grave consequences "both to the mother country and the colonies, which are equal objects of his Majesty's parental care." Furthermore, it states that the crown had no intention of

56 The Virginia Gazette, May 16, 1766, accessed on December 12, 2010, http://research.history.org/DigitalLibrary/VirginiaGazette/VGImagePopup.cfm?ID=1655\&Res=HI 57 Peter Linebaugh and Marcus Rediker, The Many-Headed Hydra: Sailors, Slaves, Commoners, and the Hidden History of the Revolutionary Atlantic (Boston: Beacon Press, 2000), 212. 
implementing "any encroachments on the real rights and liberties of any part of his Majesty's subjects." ${ }^{, 58}$ While it seems reasonable that the letter should have eased the minds of the colonists, the reality was much more alarming. On October 24, 1765, Conway wrote a letter to the commander of British forces in North America, Major General Thomas Gage, and all of the colonial governors stating that if lenient measures proved unsuccessful, they were to employ "such a timely exertion of force as may be necessary, and to provide for the maintenance of peace and good order in the provinces." ${ }^{, 59}$ A second letter to General Gage was sent on December 15, 1765 reaffirming the previous orders but again stressing that force should be used if necessary. This change in attitude from the previous letter may be due to an anonymous letter Conway received on September 24, 1765 which detailed the various acts of violence taking place in Massachusetts and Rhode Island. The letter included descriptions of violence and vandalism against the stamp distributors, plans to destroy the stamps and the stamp offices, and the coercion of stamp officials to resign. ${ }^{60}$ These letters imply that crown and Parliament were not going to compromise when it came to Parliament's right to legislate and tax the colonies.

In London, support for the colonists generated from different sources. A letter dated January 17, 1766 from the merchants of London urged Parliament to repeal the Stamp Act, not because they believed it was unconstitutional but because the taxes had the potential to "disturb legal commerce and harass the fair

58 Cobett's Parliamentary History, pp. 112,113.

59 Ibid, 116.

60 Ibid, pp. 123, 124. 
trader" and "have so far interrupted the usual and former most fruitful branches of their commerce, restrained the sale of their produce, thrown the state of several provinces into confusion, and brought on so great a number of actual bankruptcies." ${ }^{\prime 1}$ Another letter from a holding company in London states that the colonies were having enough difficulty paying for goods from England without the Stamp Act. The letter argues that "if this cursed act is not repealed, we shall be great sufferers, and our manufacturers thrown on our parishes, for want of support, whilst people who employed them, will not be in a much better situation."62 The significance of these letters is that they gave Parliament, as will be shown, a means to repeal the Stamp Act without having to admit to its unconstitutionality.

There was much support for Parliament in London as well, especially from certain merchants that blamed the damage to trade on colonial sedition instead of on the acts of Parliament. In one such letter the author complained that the House of Representatives in Massachusetts treated the "acts and resolutions of the Parliament of Great Britain" with the utmost disrespect and that the colonists planned to form a general congress without the permission from crown or Parliament. $^{63}$

What the colonists were arguing, and essentially what Parliament was contesting, was that an important aspect of British government was that use and custom were as important as any written statute or law. Jack P. Greene writes that

61 Cobbett's Parliamentary History, 134.

62 The Newport Mercury, November 18, 1765.

63 Cobbett's Parliamentary History, 121, 122. 
the colonists believed Parliament could not tax the colonists because the colonial assemblies had imposed and raised taxes with the complete acknowledgment of the king and Parliament for more than 100 years. ${ }^{64}$ With all the opposition in the colonies and with the measures clearly not generating any revenue, Parliament opened the debate on the Stamp Act on January 14, 1766.

64 Greene, 75. 


\section{Repealing the Stamp Act}

To begin the debate on whether to repeal the Stamp Act the House of Commons, in committee, examined Benjamin Franklin over the arguments from the colonies. Edmund Morgan aptly describes the session by stating Franklin

"Gracefully answered the questions put to him, including a large number of planted ones, and succeeded in conveying the impression that the Americans were a parcel of devoted children much oppressed by the Stamp Act and much less radical in their demands than they actually were." 65

While this is certainly the case, it will be important to analyze some of Franklin's testimony in order to gain a better understanding of the constitutional argument that the colonists were making.

Parliament thought they had an opportunity to outsmart the colonists by asking leading questions that might force Benjamin Franklin into answering in such a way that would validate the various acts of Parliament. In the end, Franklin was very specific about what, in his opinion, the colonists were contending.

Asked whether the colonists could pay the taxes imposed by the Stamp Act, Franklin responded that not all colonists could bear the same amount of taxes. Colonists in the east would have to bear the burden of the poorer colonists on the frontier. Furthermore, based on the estimates of the Stamp Act, Franklin

65 Morgan, 31. 
concluded "there is not gold and silver enough in the colonies to pay the stamp duty for one year." Franklin's conclusion is supported by a letter to the First Lord of Trade in which he argues that the colonists are unable to pay for the goods they need from England and the Stamp Act constitutes a "heavy burden" and has "thrown the Commerce with America into confusion." 66 Also, according to Franklin, the colonists imported more than was exported at the rate of 10 to 1 and therefore Great Britain should have no reason to extort any more from the colonists. $^{67}$

Parliament then asked Franklin about the legitimacy of providing protection for the colonists. He disagreed stating "that is not the case. The colonies raised, clothed and paid, during the last war, near 25,000 men, and spent many millions" and, he added, the crown has reimbursed the colonists much less than it had spent. ${ }^{68}$ Franklin then answered a series of questions regarding Parliament's power over the colonists, specifically the right to tax them in which he said the proposed taxes were unconstitutional because there was no representation of the colonists in Parliament. ${ }^{69}$ Franklin's distinction was between external and internal taxes. External taxes were constitutional because they were imposed on imported goods. Internal taxes were imposed directly on the subjects, and since there was no representation, these taxes, constitutionally, could not be imposed. Franklin expressed "the Stamp Act says, we shall have no

66 The New-Hampshire Gazette and Historical Chronicle, November 15, 1765.

67 Cobett's Parliamentary History, 138.

68 Ibid, 139, 140.

69 Ibid, 142 
commerce, make no exchange of property with each other, neither purchase nor grant, nor recover debts; we shall neither marry nor make our wills, unless we pay such sums, and thus it is intended to extort our money from us, or ruin us by the consequences of refusing to pay it., ${ }^{, 70}$

Franklin made his final and most compelling argument by stating that the colonists were either part of the realm or not. If they were part of the realm, then Parliament had the right to levy taxes. However, Parliament did not have the right to levy taxes on those without representation and if the colonies were indeed part of the realm, they should then have representation. If they were not part of the realm, like Ireland, then the assemblies levied the taxes. ${ }^{71}$ One final note on Franklin's examination before Parliament: He made it clear that the colonists were loyal subjects and only wished their relationship with Great Britain be returned to the status it was before the French and Indian War. He adds, however, that if British troops were sent to the colonies to enforce the tax, they would not find rebellion, but they may start rebellion. ${ }^{72}$ Franklin's opinion was that the colonist's belief that the Stamp Act was not constitutional was correct and that any attempt by Parliament to the contrary may lead to rebellion. This is an example of how both sides were unwavering in their interpretation of the British Constitution.

The House of Commons then put to vote a resolution to repeal the Stamp Act. Before the vote took place, however, several clauses were added to the bill.

70 Ibid, 144.

71 Cobett's Parliamentary History, 156.

72 Ibid, 147. 
As well as repealing the Stamp Act, the new bill would assert that Parliament had supreme power in making laws and statutes to bind the colonists to Great Britain. It also condemned the actions in the colonies, especially in the various assemblies which were conducted "in open defiance of the powers and dignity of his Majesty's government."73 These two points were either lost on the colonists or conveniently ignored as they were satisfied that the Stamp Act was repealed. One clause that failed to make it into the bill stated "all votes and resolutions made by the assemblies (in opposition to the Stamp Act) in the colonies are to be erased."74 The bill passed the House of Commons and was sent to the House of Lords.

Before opening debate on the bill, the House of Lords issued a series of statements identical to the House of Commons. Specifically, they stated that the king and Parliament had supreme power over the colonists, the acts of the assemblies in the colonies were defiant to the crown and Parliament, and notices needed to be sent to the assemblies ordering them to cease such activities. ${ }^{75}$

The debate in the House of Lords not only dealt with the possibility of repealing the Stamp Act but also with what to do with the colonists. Lord Shelbourne favored repealing the Stamp Act and restoring the relationship with the colonies to what it was prior to the French and Indian War. His reasoning was that if Parliament exercised its right to enforce the Stamp Act it would actually cost more than they ever could hope to gain by the tax. ${ }^{76}$ To be sure, he by no

73 Ibid, 162.

74 Ibid, 163.

75 Cobett's Parliamentary History, 165.

76 Ibid, 166. 
means stated he thought the colonists were correct, he simply wanted to avoid the trouble opposing them would create.

Lord Lyttelton argued that when the colonists left Britain, they did so as subjects to the crown and "if the colonies are subjects of Great Britain, they are represented and consent to all statutes." He also warned "by declaring them exempt from one statute or law, you declare them no longer subjects of Great Britain, and make them small independent communities not entitled to your protection" 77 This became a common theme among the members of the House of Lords. Quite simply, they argued for an all or nothing resolution. Either the colonists were absolutely bound to the king and Parliament or they were not subjects at all.

Lord Chancellor Northington argued that King William passed an "act avowing the power of the legislature over the colonies." He suggested that if the colonists "withdraw allegiance you must withdraw protection; and then the little state of Genoa, or the kingdom or rather republic of Sweden, may soon overrun them." ${ }^{, 78}$ He believed the threat of removing the protection of the empire might cause the colonists to accept Parliament's authority.

Lord Mansfield argued from a constitutional position. He contended that:

"The British legislature, as to the power of making laws, represent the whole British empire, and has authority to bind every part and every subject

77 Ibid, 167.

78 Ibid, 171. 
without the least distinction, whether such subjects have a right to vote or not, or whether the law binds places within the realm or without."

In essence, Mansfield argued that Parliament had supreme authority in all matters. He continued, "how did representation by election first arise? Why, by the favor of the crown. And the notion now taken up, that every subject must be represented by a deputy, if he does not vote in Parliament himself, is merely ideal." He did not offer a compromise: "I know no difference between laying internal and external taxes" and "when the supreme power abdicates, the government is dissolved." ${ }^{, 79}$ Mansfield did not have many supporters in the House of Lords for this argument.

Lord Camden also argued constitutionally but in favor of the colonists. "In my own opinion, my lords, the legislature had not the right to make this law . . . they (Parliament) have no right to condemn any man by bill or attainder without hearing him . . every subject must make contribution. And this he consents to do by his representative." 80 However, he opposed the current bill because it asserted absolute authority over the colonies at the same time the Stamp Act was repealed. He then gave several examples in which Parliament allowed communities that were not represented to tax themselves. He quoted a 1674 case where the clergy were about to be taxed and after they protested Parliament granted them the right to tax themselves. Similarly, the counties

79 Cobett's Parliamentary History, 176.

80 Ibid, 168. 
palatine refused to allow taxation until they had representation. When representation was given, they dropped their protest. Wales was not taxed until it was given representation in Parliament. Lord Camden's opinion was that "the colonists had the right to tax themselves, and the Parliament not.",81

Another argument during the debate in the House of Lords was that Parliament had the right to tax any of the subjects of Great Britain regardless of representation. One member argued "because not only the right, but the expediency and necessity of the supreme legislature's exerting its authority to lay a general tax on our American colonies, whenever the wants of the public make it fitting and reasonable that all the provinces should contribute, in a proper proportion, to the defense of the whole, appear to us undeniable." 82 Camden countered that even in places were there was representation, the absolute authority of Parliament to levy taxes was debatable.

There were other voices during the debate including this in the House of Lords: "The total repealing of that law, especially while such resistance continues, would make the authority of Great Britain contemptible hereafter." 83 This was a common fear, that repealing the bill would embolden the colonies. Here is the key argument and fear of Parliament:

"Because the appearance of weakness and timidity in the government and Parliament of this kingdom, which a concession of this nature may too

81 Cobett's Parliamentary History, 170.

82 Ibid, 184.

83 Ibid, 182. 
probably carry with it, has a manifest tendency to draw on further insults, and, by lessening the respect of all his majesty's subjects to the dignity of his crown, and authority of his laws." $\$ 4$

Those that believed in the absolute supremacy of Parliament also believed in securing that power with any means necessary. Although the root of the argument was over representation and use and custom of the constitution, these particular members of Parliament believed it was paramount that their power was immediately reestablished.

In essence, the colonists were using the same arguments against Parliamentary power as the Parliament had used against royal power a century earlier. This was problematic for Parliament as it was essential that they prevented the colonists from undermining their power. While most members agreed that Parliament had the right to tax the colonists, they also understood that asserting the right at that time would be more costly than repealing the tax. ${ }^{85}$ In the end, the House of Lords repealed the Stamp Act, and the relationship between Great Britain and the colonists was nearly restored to what it was before the French and Indian War.

The repeal should have been the end of the crisis in the colonies.

However, members of Parliament, in an effort to legislate their interpretation of the Constitution, passed an act to secure supreme power over the colonies.

84 Ibid, 186.

85 Repeal of the Stamp Act failed to pass in the House of Commons until the Declaratory Act was attached suggesting most members of Parliament believed they had the right to tax the colonists. Middlekauff, 121. 
During the debates over whether Parliament should repeal the Stamp Act, King George III replaced Grenville with the Marquis of Rockingham as prime minister for what were characterized as personal reasons. Rockingham found himself in the position of having to deal with an act he had no means of enforcing. As a result he wanted to make sure the repeal passed the vote in the House of Lords. There were still a number of members that refused to support the repeal because they were sure it would lead to future abuse by the colonists. To sway their votes, Rockingham drafted the Declaratory Act. ${ }^{86}$ As mentioned earlier, the Declaratory Act was worded almost identical to its Irish counterpart. Not only did it state that Parliament had the power to make laws and statutes to bind the colonies in "all things whatsoever," it also prefaced the declaration by stating that this power was being reaffirmed because of the colonists' recent objections to Parliament's right to tax and of the colonial assemblies' recent resolutions stating Parliament did not have those rights. ${ }^{87}$

Edmund Morgan writes that the term "tax" was replaced with "laws and statutes" to keep the colonists from becoming alarmed. ${ }^{88}$ William Pitt, a member of the House of Lords who agreed with the colonists' point of view tried unsuccessfully to have the phrase "in all things whatsoever" removed from the act as he knew that too many in the House of Lords believed it applied to taxation as well. The Declaratory Act was passed immediately after the Stamp Act was

86 Morgan, 31.

87 Yale Law School, “Avalon Project: Documents in Law, History, and Diplomacy,” Lillian Goldman Law Library, Http://avalon.law.yale.edu/18th_century/declaratory_act_1766.asp.

88 Morgan, 32. 
repealed. Regardless of the wording, Jack P. Greene argues that the Declaratory Act, despite the fact that its Irish predecessor was never enforced, was a warning to the colonists "that Parliament had kept the door open to some future attempt" to levy more taxes on the colonists. ${ }^{89}$

Based on the reactions to the Stamp Act, it is clear that both Parliament and the colonists had differing opinions regarding how the British Empire should be governed. Both arguments were based on differing interpretations of the British Constitution. The colonists had always been left relatively alone to govern themselves and they felt it was their right to do so. Many members of Parliament felt that they had the power to govern the British Empire in whatever way they felt was most effective within their own interpretation of the British Constitution. In the years immediately following the French and Indian War Parliament significantly changed its policy towards the colonists. At first it was merely a change in the economic policies but would soon include its military policies which would further exacerbate the strained relationship between Parliament and the colonists.

89 Greene, 101. 


\section{Constitutional questions and reactions to the repeal of the Stamp Act}

The repeal of the Stamp Act and the subsequent actions by Parliament served to further define and galvanize the colonists interpretation of the English Constitution. To briefly summarize, Great Britain needed to raise funds due to a post-war recession. Grenville saw an opportunity to levy taxes on the colonists. As has been shown, many colonists protested, claiming the taxes were unconstitutional. Parliament repealed the Stamp Act, not because it found it unconstitutional but because it was deemed too difficult to enforce. Parliament then passed an act stating that it had the power to pass laws and statutes for the colonies in "all things whatsoever." In essence, the British constitution as a source for both the arguments of Parliament and the colonists created problems in itself. In the end, the British constitution was used by Parliament to justify the change in policy seen throughout the years prior to the American Revolution and was used by the colonists to justify their arguments against that change. What follows is a brief examination of how the constitutional arguments fueled the reactions to the passage and repeal of the Stamp Act and the subsequent acts of Parliament.

The constitutional question is difficult for several reasons. The Irish Declaratory Act was a precedent for the validity of the Declaratory Act passed in 1766. Additionally, if Parliament debated, voted for, and passed an act, did that make the act constitutional regardless of what it stated? According to Lewis 
Namier, the possibility is that members of Parliament were primarily concerned with retaining their influence locally instead of concerning themselves with the rights of the colonists. ${ }^{90}$

As stated earlier, some members of Parliament argued that the question of representation was never an issue. There were many people within the boroughs of Great Britain that did not have a right to vote yet were considered represented nonetheless. Some argued that the very fact that the colonists were considered lawful subjects of Great Britain infers they were represented. The idea was that all members of Parliament, although elected to represent certain localities, actually represented the entire realm. They called this "virtual representation." Therefore, the argument was that although there were no representatives from the colonies, the colonists were indeed represented in Parliament. This meant that many members of Parliament believed they were acting constitutionally when they passed the Sugar Act, Stamp Act, and the Declaratory Act. When they were forced to repeal the Stamp Act because of what they saw as blatant colonial insubordination, they were worried that future attempts to legislate in the colonies would be met with the same reaction. At the very least members Parliament wanted to reassert their authority over the colonists. Robert Middlekauff aptly explains Parliament's attitude when he writes "whatever the distinctions that the colonies made between legislation and taxation, the fact remained that they had challenged a right Parliament had long cherished. How to blunt that challenge, or

90 Lewis Namier argues in England in the Age of the American Revolution (1930) that political struggles in Parliament focused more on securing influence and power locally rather than any ideological concerns they may have had regarding the colonies. 
better yet how to bury it?"91

It was these attitudes that led Parliament into taking any means possible to reassert authority over the colonists. In an address to the king in 1768 regarding the resistance to Parliaments acts in the colonies, the House of Common wrote that they would "maintain entire and inviolate the supreme authority of the legislature of Great Britain over every part of the British Empire."92 The House of Lords likewise assured the king that in regards to colonial resistance they would "maintain inviolate the supreme authority of the legislature of Great Britain over every part of the dominion of your Majesty's crown." ${ }^{93}$ However, they were unaware, either through arrogance or ignorance, how the colonists would react. They hoped that a strict unwavering resolve backed by the might of the British Army would quickly correct the behavior of the colonists.

Indeed, it was not lost on the colonies what was happening in London. Based on the transcripts from Parliament, they understood that it was difficult for the government to enforce the Stamp Act. They also understood and had read the arguments stating that if the act was appealed, they would be more likely to oppose every legislation to come from Parliament.

This was of concern to some merchants in London. In a letter from the Committee of Merchants in London to the Merchants of Newport, the colonists were congratulated on the repeal of the Stamp Act but were warned to be gracious. The letter states that any celebration would surely be seen as a

91 Middlekauff, 114.

92 Cobett's Parliamentary History, 474.

93 Ibid, 471. 
vindication of the colonists over the sovereignty of Parliament. This letter arrived on the heels of the Declaratory Act and was most likely intended to keep the colonists from reacting in the same way they had acted against the Stamp Act. Surely, it was in the best interests of the merchants that trade continued unabated. ${ }^{94}$ Clearly, merchants and other people in London were very concerned about the behavior of the colonists before the Stamp Act was repealed. Another letter from London sent to the colonists urged them to rejoice that they were subjects of a just and kind government and warned against undermining that kindness over trivial matters. ${ }^{95}$ Letters such as these seem unnecessary if only the Stamp Act had been repealed. In light of the subsequent Declaratory Act, it seems people in London were very wary about the reactions in the colonies. Reaction to the Declaratory Act was relatively swift. Many newspapers included commentaries on the act asserting that it violated the same principles and rights that rendered the Stamp Act invalid. For example, a letter in the August 1, 1766 issue of The Maryland Gazette states "no Parliament can alter the nature of Things, or make that good which is really evil. If they could do this, then they might alter the whole Frame of the Constitution where they are chosen - They might make them-selves independent on their constituents, and be perpetual dictators. ${ }^{" 96}$ In an August, 1766 issue of the Boston Evening Post a commentary entitled "The Crisis" reasserted that Parliament did not have the right to impose a tax on a subject without their consent. The author also

94 The Newport Mercury, May, 1766.

95 Connecticut Courant, November, 1766.

96 The Maryland Gazette, August 1, 1766. 
answered the argument made by members of Parliament that the colonists were "virtually represented" in Parliament by stating that to be properly represented, a subject must have an advocate that has the ability to petition Parliament. He states that since Parliament had made it a common practice to refuse any petitions made by the colonists, they were not properly represented. ${ }^{97}$ The right to petition was an important aspect of the colonists' argument for a couple of reasons. The Magna Carta states that any grievances may be addressed to the barons. ${ }^{98}$ Unless at least four barons agreed to the petition, it would not be forwarded to the king. The Bill of Rights of 1689 states "it is the right of the subjects to petition the king, and all commitments and prosecutions for such petitioning are illegal."99 The colonial argument was that the Bill of Rights granted the right to petition to all subjects individually. The opposition in Parliament stated petitions must be submitted through the proper representatives. Those representatives, according to the colonists, did not exist.

Lord Chatham, hero of the French and Indian War and a well-respected legislator, addressed Parliament defending his long-standing opposition to the Declaratory Act. The address was published in the Pennsylvania Chronicle in December of 1767. Chatham repeated that taxation and representation were inseparable and "no man hath a right to take it (property) from him without his consent" and "whoever attempts to do it destroys the distinction between Liberty

97 Unknown, "The Crisis," Boston Evening Post, August, 1766.

98 Yale Law School, “Avalon Project: Documents in Law, History, and Diplomacy," Lillian Goldman Law Library, http://avalon.law.yale.edu/medieval/magframe.asp

99 Yale Law School, “Avalon Project: Documents in Law, History, and Diplomacy," Lillian Goldman Law Library, Http://avalon.law.yale.edu/17th_century/england.asp. 
and Slavery." Chatham then challenged Parliament to name any time when a person was taxed without representation. He then cites several occasions where Parliament attempted to tax without due process and those cases were judged to be unconstitutional and concludes that taxation without representation "destroys the distinction between Liberty and Slavery." 100

John Dickinson, a legislator in Pennsylvania published a series of letters in 1767 and 1768 under the pseudonym of "The Farmer" which outlined his reactions to the Declaratory Act as well as the Townsend Acts, which will be examined later. These letters are significant because they were published throughout the colonies and were instrumental in helping to unite the colonists. In the first letter, Dickinson called on the colonies to remain united in the current crisis. While he was opposed to violence in reaction to British infringement on the rights of the colonists, he asserted that the idea of taxation without representation was unconstitutional such as had been argued by Benjamin Franklin and Lord Chatham. He concluded that the colonists must remain vigilant and support each other in order to protect their rights guaranteed by the constitution. $^{101}$

Thomas Jefferson greatly opposed the Declaratory Act and tried to warn fellow colonists of how far Parliament had gone by stating "by one Act they have suspended the powers of one American legislature, and by another have declared they may legislate for us themselves in all cases whatsoever. These two acts

100 Pennsylvania Chronicle, December, 1767.

101 John Dickinson, Empire and Nation: Letters from a Farmer in Pennsylvania (John Dickinson), ed. Forest McDonald (Indianapolis: Liberty Fund, 1999). Chapter: Letter I. 
alone form a basis broad enough whereon to erect a despotism of unlimited extent."102

Jefferson was not alone with his concern. A number of gentlemen from Fauquier County, Virginia sent a letter to the House of Burgesses which was published in the April 14, 1769 edition of The Virginia Gazette in opposition to the Declaratory Act. It states:

"We look upon all attempts at taxation upon from a British Parliament, or any other power on earth, without our consent constitutionally given by our Representatives, to be totally inconsistent with the principles of liberty, and the greatest insult that can be offered to free-born subjects."

If the reaction to the Declaratory Act was swift, it was not pervasive. ${ }^{104}$ Commentaries appeared sporadically throughout 1766 and into 1767 expressing concern over the act. But since the Stamp Act was repealed and no new acts had been passed, the colonists did not have anything substantive in which to object. In London, however, Rockingham's colleague and strong ally, Charles Townshend, was working on a series of acts that would reignite the crisis in the colonies. The Townshend Acts included five separate acts each of which imposed

102 Thomas Jefferson, The Writings of Thomas Jefferson, Volume 1. Edited by Paul Leicester Ford (New York: G.P. Putnam's Sons, 1892) 469.

103 The Virginia Gazette, April 14, 1769, accessed on January 13, 2011, Http://research.history.org/DigitalLibrary/VirginiaGazette/VGimagePopup.cfm?ID=2550\&RES=HI\&C FID $=9090659 \&$ CFTOKEN $=68247007$

104 The Virginia Gazette, Connecticut Courant, Maryland Gazette, Massachusetts Gazette Extraordinary, and The Pennsylvania Chronicle each had a handful of articles regarding opposition to the Declaratory Act. Many of the articles were duplicates. 
higher taxes, tightened regulations, and provided for more control over currency. Three of the acts are important to this discussion.

The first of the Townshend Acts, known as the Revenue Act, was Townshend's answer to the colonists' opposition to internal taxation by Parliament. In essence, Townshend compiled a list of the items that the colonists did not manufacture in North America and, by law, had to be purchased directly from Great Britain. By placing a duty on these items it appeared Townshend had created a tax that the colonists could not oppose based on their arguments regarding internal and external taxes. ${ }^{105}$

To enforce the Revenue Act, Parliament passed the Commissioners of Customs Act and the Vice Admiralty Court Act. The first of these acts created the American Board of Customs Commissioners which primarily dealt with the efficient enforcement of the new duties. The Vice Admiralty Court Act expanded the court responsible for hearing cases regarding duties and customs. Both of these entities further alienated the colonists from Great Britain. According to Middlekauff, the officers charged with enforcing the duties were a constant reminder to the colonists that Parliament sought to undermine their rights while the expanded courts was a blatant infringement on their right to be tried by a jury of their peers. ${ }^{106}$

Additionally, Parliament sent two regiments of the British Army to Boston in 1768. The official reason for the deployment was for the further protection of

105 For a list of items and the duties imposed on them by the Townshend Revenue Act, refer to the document at Http://avalon.law.yale.edu/18th_century/townsend_act_1767.asp.

106 Middlekauff, 156. 
the colonists. Some colonists understood the presence of the troops was to protect the official government agents in the colonies and to maintain a visible force to discourage any colonial protest. In a letter published in The Virginia Gazette on November 10,1768, the author states that the government was "now determined to enforce the acts of Parliament at all events, and God knows what will be the consequence," and that it was reported that Boston has become the headquarters for the British Army. ${ }^{107}$ Several citizens of Boston issued a petition to the Massachusetts Assembly instructing them to remove the British Army from Boston because "debates there (the assembly) must be free" and that they should "exert themselves to remove every thing that may carry the least appearance of an attempt to awe or intimidate."108 The commissioners, according to Edmund Morgan, were a skittish group and at the first sign of unrest sent panicked letters to Parliament requesting assistance. Parliament had grown impatient with the colonists and "were easily convinced that the time had come to teach the Americans a lesson, and for this particular lesson they thought the best qualified instructors would be the regular troops of the British Army."

According to Greene, the Townshend Acts, much like the Stamp Act, caused the colonists to "examine their constitutional situation more closely and critically than they have ever done before" and had, by 1770, a "better

107 The Virginia Gazette, November 10, 1769, accessed on January 13, 2011, Http://research.history.org/DigitalLibrary/VirginiaGazette/VGImagePopup.cfm?ID=2112\&Res=HI\&CF $\mathrm{ID}=10788416 \&$ CFTOKEN $=35918089$

108 The Virginia Gazette, June 8, 1769, accessed on January 13, 2011, Http://research.history.org/DigitalLibrary/VirginiaGazette/VGImagePopup.cfm?ID=2385\&Res=HI\&C FID $=10788416 \&$ CFTOKEN=35918089 109 Morgan, 42. 
understanding of the nature of their politcal situation."110 Greene likened this situation to the same revelations discovered by members of Parliament in the seventeenth century. By 1770 , due to a better understanding of their political situation and the validity in their minds of the idea of usage and custom, most colonists were not willing to compromise with Parliament. Neither were most members of Parliament willing to compromise with the colonists.

Reaction to the Townshend Acts was not as swift as it was for the Stamp Act. John Dickinson's letters were perhaps the most critical of Parliament. He wrote that the meaning of the letters was to "convince the people of these colonies that they are at this moment exposed to the most imminent dangers; and to persuade them immediately, vigorously, and unanimously, to exert themselves in the most firm, but most peaceable manner, for obtaining relief." He was clear, however, that there were some in the colonies who would try to incite the colonists to rise up in a most violent and treacherous way. He urged restraint in acting rashly and instead encouraged the colonists to seek a constitutional remedy for the current crisis. Dickinson did, however, recognize that peaceful measures may not yield favorable results and, as history has shown, sometimes freedom must be defended at the point of a blade. ${ }^{111}$

If the colonists were opposed only to internal taxes and if the Townshend Revenue Act can be considered an external tax, the question can be asked why there was any opposition at all. John Dickinson explained the prevailing point of

110 Greene, 159.

111 John Dickinson, Empire and Nation: Letters from a Farmer in Pennsylvania (John Dickinson), ed. Forest McDonald (Indianapolis, Liberty Fund, 1999). Chapter: Letter III. 
view in a subsequent letter. There really was no difference between an internal and external tax. A "tax" was an imposition with the intent for levying money. Money, being property can not be levied by the sovereign or by Parliament without the consent of the subject either personally or through his representative. Therefore Dickinson argued that the Townshend Revenue Act was unconstitutional. ${ }^{12}$

It should be added that even if the the Townshend Revenue Act could be shown to be an external tax as defined by Benjamin Franklin during his examination before Parliament, there were other factors involved that would cause unrest within the colonies. Specifically, as stated above, the mere existence of the American Board of Customs Commissioners, the two regiments of the British Army in Boston, and the expansion of the Vice Admiralty Courts, whose purpose in the eyes of the colonists was to tighten Parliamentary control in the colonies were cause for concern. Therefore, the earlier distinction between internal and external taxes was no longer an essential component in the colonists' argument. At this time it was determined that any tax imposed by Parliament on the colonies was unconstitutional. Dickinson expanded his argument on how a tax on goods imported to the colonies were, in fact, a tax on the colonists themselves. Since the taxes were applied to goods that, by law, could only be purchased from Great Britain, and those goods were arguably necessary for the continued prosperity of the colonists, and since it was assured that the sellers of

112 John Dickinson, Empire and Nation: Letters from a Farmer in Pennsylvania (John Dickinson), ed. Forest McDonald (Indianapolis, Liberty Fund, 1999). Chapter: Letter IV. 
those goods would increase the price according to the taxes applied to them, ultimately they were direct taxes on the colonists. ${ }^{113}$

Regarding the Vice Admiralty Courts, Dickinson argued that since they were courts with judges appointed by Parliament with no juries, it was inherently dangerous to the freedom of the colonists. Justice is only served, explained Dickinson, "before independent judges who are no parties in committing the injury." Since the Vice Admiralty Courts were created by Parliament to help enforce the acts of Parliament with judges appointed by Parliament, justice could not be served. ${ }^{114}$

Dickinson believed that the preservation of freedom within the colonies could not be achieved through unrest, violence, or any unreasonable method of protest. Freedom would come through the same measures taken during the Stamp Act crisis. That is, through resolutions in local assemblies, petitions to both the crown and Parliament, and a vigilant display to the world that the colonists were aware of their rights, were worthy of possessing them, and magnanimous enough to deserve the respect contained within those rights. ${ }^{115}$

There were other official reactions to the Townshend Revenue Act, such as the Boston Non-Importation Agreement of 1769, and the Charleston NonImportation Agreement of 1769. These agreements were the result of a circular

113 John Dickinson, Empire and Nation: Letters from a Farmer in Pennsylvania (John Dickinson), ed. Forest McDonald (Indianapolis, Liberty Fund, 1999). Chapter: Letter VII.

114 John Dickinson, Empire and Nation: Letters from a Farmer in Pennsylvania (John Dickinson), ed. Forest McDonald (Indianapolis, Liberty Fund, 1999). Chapter: Letter IX.

115 John Dickinson, Empire and Nation: Letters from a Farmer in Pennsylvania (John Dickinson), ed. Forest McDonald (Indianapolis, Liberty Fund, 1999). Chapter: Letter XII. 
letter written in Massachusetts in 1767 which reiterated their claim that it was unconstitutional to take subjects' property without their consent and that the subjects should disregard the Townsend Acts. ${ }^{116}$ The non-importation agreements stated that, whenever possible, goods would not be imported from or exported to Great Britain. In both cases, the agreements would be canceled if the Townshend Acts were repealed. ${ }^{117} \quad$ Women also became heavily involved in the nonimportation agreements as is evidenced in a December, 1767 issue of the The Massachusetts Gazette Extraordinary which reported that a number of prominent ladies in Boston got together to manufacture their own essentials such as clothing and linen and only consumed products manufactured in the colonies. ${ }^{118}$ Lastly, assemblies from many of the colonies, including Pennsylvania, Virginia, and Massachusetts sent petitions to King George III requesting that the acts be repealed. As a result, the governors of Massachusetts and Virginia dissolved the assemblies. Parliament refused to acknowledge any of the petitions sent from the colonies.

In 1770, Parliament partially repealed the Townshend Acts. Prime Minister Lord Frederick North considered the acts bad for trade and expected they would generate less revenue than Townshend had hoped for. However, Parliament clearly believed they had every right to pass the various acts in an

116 Journals of the House of Representatives of Massachusetts, Boston: Green and Russel, [17671768], http://www.masshist.org/revolution/doc-viewer.php?old=1\&mode=nav\&item_id=289

117 Yale Law School, “Avalon Project: Documents in Law, History, and Diplomacy,” Lillian Goldman Law Library, http://avalon.law.yale.edu/18th_century/charleston_non_importation_1769.asp, and http://avalon.law.yale.edu/18th_century/boston_non importation_1769.asp.

118 The Massachusetts Gazette Extraordinary, Number 3351, 24 December 1767 (Boston: Published by Richard Draper, 1767). 
attempt to address the economic problems facing the empire. That a large majority of the taxes were repealed was not a testament to the strength of the colonists' argument or Parliament's concession thereof. It seems clear that the difficulty in enforcing the taxes or the lack of revenue generated was the reason for the repeals. The colonists and Parliament continued to disagree over how the colonies should legally and constitutionally be governed. Therefore, Parliament's change in policy toward the colonists continued into the 1770 s with a greater effort on enforcement to include the use of the British military. 


\section{The Eve of Revolution}

The events of 1769 and 1770 mirrored the earlier attempts by Parliament to levy taxes on the colonists. Indeed, by 1770 Parliament's change in policy towards the colonists appeared to be business as usual in London. There was not a steady escalation of this policy over the years. Parliament tried to levy taxes in the colonies in different ways: The Stamp Act, the Townshend Acts, the Tea Act, etc. The colonists continued to oppose what they believed were infringements upon their constitutional rights and their right to self-govern. What is not seen is an escalation of acts with the intent of taxing North America and thus angering the colonists to such an extent that results with inevitable revolution. Even the Declaratory Act, which essentially stated that the colonists had no power to resist Parliament, was not a volatile enough issue to cause war between Great Britain and the colonists.

When the Stamp Act was repealed, the unrest in the colonies subsided. When the Townshend Acts were passed, protest was generally peaceful and for the most part confined to official petitions, declarations, and protest through print. Except in Boston, where violence did break out from time to time (and was subsequently exaggerated in the reports to London), the colonists remained relatively calm. Once the Townshend Acts were repealed in 1770 there were about three years of peace in North America. The colonists paid their taxes and if they disagreed in principle on the tea tax, protests were not common. 
The issue over the extent of Parliament's power was not forgotten and the relative peace of the early 1770 s was very fragile. These years, although more stable than during the Stamp Act crisis, were nervous years for both the colonists and the royal officials in North America. It is for that reason that the situation deteriorated so quickly in 1773 . However, it is not the reason that the situation deteriorated in the first place.

The situation was complicated and pointing to any single issue as the sole cause of the American Revolution would be misleading. However, the colonists were living in an environment that was increasingly volatile. Parliament created this environment in the name of protecting the colonists and enforcing the laws. Although Parliament had twice been forced to repeal laws due to what appeared to be colonial disobedience, it was no surprise that Parliament would take advantage of any opportunity to demonstrate to the colonists that they were the authority in the empire.

When Parliament created a virtual monopoly on tea by allowing the East India Trading Company to bypass wholesale merchants, the residents of Boston did not allow the tea to be unloaded from the ships. Instead, they dumped the tea into the harbor. Parliament decided to wholly commit to its new policy towards the colonies and passed a series of acts over the next couple of years that drove the colonists to open rebellion.

The colonists, on the other hand, felt they were continuing to defend their constitutional rights as they had the past. They were successful in repealing the 
Stamp Act and most of the Townshend Acts and were content to pay the duties on tea so long as Parliament left it at that. The American Revolution occurred because Parliament and many colonists disagreed over the constitutionality of Parliament's actions. While Parliament believed they had supreme power to legislate and tax the colonies, many colonists felt that lack of representation and the ideas of custom and usage prohibited them from doing so.

In essence, even as late as 1776 , the colonists as a whole were not interested in war with Great Britain, but they believed the "intolerable acts" were unconstitutional legislation and the ever-increasing presence of the military left the colonists with few options other than to resist forcibly. 


\section{Conclusion}

George III and Parliament were faced with an economic crisis that required immediate attention. To that end, Parliament changed its policy in how it governed the colonists. This change in policy and the subsequent reaction to colonial resistance left the colonists feeling that their constitutional rights were in immediate danger. The American Revolution occurred in direct response to Parliament's change in policy. More specifically, it was the unwavering disagreement over the nature of the constitution that caused the American Revolution.

What could be considered constitutional under British law in the eighteenth century was difficult to determine. When faced with the Stamp Act, the colonists tried to prove to Parliament what their constitutional rights were. To do this they first needed to prove that they were, indeed, full subjects of Great Britain entitled to all the rights of their counterparts across the Atlantic Ocean. There was no controversy regarding this fact as George III specifically affirmed they were full subjects in a speech to Parliament. The colonists then needed to prove that, as subjects, they could be taxed only by their own consent either personally or through their representatives. This was perhaps the most difficult task because it assumed several things. First, that the British constitution did indeed state taxation could only occur through representation. Secondly, that they could prove that they were not represented in Parliament. Lastly, and most 
importantly, Parliament would need to agree with these assessments and legislate accordingly.

The Magna Carta clearly states that no man can be separated from his property without due process. In the seventeenth century Parliament made the decision that only Parliament could pass legislation or levy taxes and this power was given by consent of the people. The Bill of Rights of 1689 solidified the power of Parliament to pass legislation and levy taxes and also reaffirmed that Parliament existed by the consent of the people. Based on these facts and the precedents provided to Parliament, the colonists believed they had successfully argued their case. But most members of Parliament believed they had supreme authority over the colonies. However, Parliament repealed the Stamp Act, not because they believed it was unconstitutional, but because they believed it was too difficult to enforce.

While the colonists were victorious with the repeal of the Stamp Act, it came at a price. Parliament passed the Declaratory Act which legislated the supreme authority they believed they already held. As Edmund Morgan puts it "the members of Parliament assured themselves that they had the authority by announcing that they had it. If anyone wanted to know where it came from, it came from the announcement!",119

Another divisive act by Parliament was passing the Declaratory Act in 1766. Although Parliament did not take advantage of the act until much later, it did succeed in casting a pall over the colonies. There was constant uncertainty in 119 Morgan, 62. 
the colonies over when and how Parliament might exercise the act. Parliament exacerbated the situation when it sent troops to the colonies in order to protect the officials that were trying to enforce the Townshend Acts. The presence of armed troops always had the risk of escalating a volatile situation into violence. The Boston Massacre was a poignant example of such an escalation. Regardless, the very presence of the troops exacerbated the feeling of uncertainty among the colonists.

The people Parliament appointed to enforce the Townshend Acts and later the Tea Act were not well received in the colonies. These crown appointed officials did not help to assuage the distrust of the colonists. For example, the illegal search and seizure of vessels in Boston Harbor was evidence of the corruption employed by the officials. ${ }^{120}$ Furthermore, Parliament placed several navy vessels off of the coast of North America where they repeatedly conducted search and seizure operations that included several illegal confiscations of provisions from local merchants.

The colonists were not discouraged. The colonists reacted to the Townshend Acts with the same arguments they had used against the Stamp Act. The colonists argued that Parliament did not have the right to tax without their consent, and since they were not represented, consent was not given. Again, the colonists felt vindicated when all of the taxes in the Townshend Acts were repealed except for the tax on tea. The colonists were satisfied and the crisis

120 For an example of illegal searches and seizures of vessels in Boston Harbor, see George G. Wolkins' "The Seizure of John Hancock's Sloop Liberty.” Proceedings of the Massachusetts Historical Society 55 (1923), 239-84. 
seemed to be resolved. The colonists believed they had successfully argued that Parliament was limited in the ways it could tax them. At the same time, Parliament never conceded that they could did not hold supreme authority over the colonies.

Therefore, the issue surfaced again in the 1770s. At the first sign of unrest in Boston, the Boston Tea Party, Parliament increased its effort to take control of the administration of the colonies through the "intolerable acts." If there was opposition to these measures in England, they did not make it known. According to The Annual Register, a yearly publication from London which summarized the important political and economic activities of the previous year, the attitude of the people in Great Britain was of indifference. Several reasons were listed in the publication. Conflict in the colonies was not new and they assumed things would eventually work out like they had in the past. Additionally, economic conditions in England were difficult so they were not inclined to pay attention to what Parliament was doing concerning the colonies. Without local pressure to prevent them, Parliament "was at full leisure to prosecute the measures it had designed against America." ${ }^{121}$

Efforts in Parliament to compromise with the colonists were thwarted by influential hardliners. The colonists continued its attempts to reconcile with Parliament without surrendering their understanding of their constitutional rights. They repeatedly told Parliament that they would be satisfied if one of two things

121 The Annual Register, or a View of the History, Politics, and Literature for the Year 1775. Page 37. Accessed on September 12, 2009 at http://www.bodley.ox.ac.uk/cgibin/ilej/image1.pl?item=page\&seq=1\&size=1\&id=ar.1775.x.x.18.x.x.u1. 
happened. Either the colonies gained official representation in Parliament, which Benjamin Franklin and John Dickinson concluded would be impractical, or that the relationship between the colonies and Great Britain was restored to the way it was in 1763 .

If colonial representation in Parliament was impractical, another solution was to allow local assemblies in the colonies to act on Parliament's behalf as they had in the past. A circular letter from the Massachusetts Assembly approved of this solution by stating "his Majestys Royal Predecessors for this reason were graciously pleased to form a subordinate legislator here that their subjects might enjoy the inalienable Right of a Representation." ${ }^{122}$ For instance, Parliament could instruct the assemblies regarding what was needed in the form of taxes and let the local assemblies decide how to collect that sum. This is conjecture, as Parliament discussed the possibility of colonial representation on only a few occasions and quickly deemed it impractical. Furthermore, in the process of changing its policies and in the face of colonial resistance through the assemblies, Parliament ordered the dissolution of the assemblies. This was of great concern to the colonists. As Samuel Adams wrote in 1772:

"The inhabitants of this country, in all probability, in a few years, will be more numerous than those of Great Britain and Ireland together; yet it is absurdly expected by the promoters of the present measures that these, with their

122 Journals of the House of Representatives of Massachusetts. Boston: Green and Russell, [17671768]. Accessed on June 28, 2010 at http://www.masshist.org/revolution/docviewer.php?old=1\&mode=nav\&item id=289. 
posterity to all generations, should be easy, while their property shall be disposed of by a House of Commons at three thousand miles' distance to them, and who cannot be supposed to have the least care or concern for their real interest; who have not only no natural care for their interest, but must be in effect bribed against it, as every burden they lay on the Colonists is so much saved or gained to themselves."

Clearly, Adams was concerned they may soon have no representation at all.

All of these events were the consequence of Parliament and the colonists disagreement over fundamental constitutional issues. As such, it was Parliament's change in policy towards the colonists that caused colonial resistance. The colonists believed they proved their right to control their own taxes under the British constitution but Parliament wanted to protect and indeed expand their authority over the colonies. Jack P. Greene summarizes accurately when he writes "maintaining that legislative authority was distributed broadly and equally among the several corporate entities that composed the empire, the colonists insisted both that the legislative power of each American Parliament was as complete as that of the British Parliament." 124 The colonists would not relent on this and Parliament would not acknowledge it and events escalated until Great Britain and the North American colonies were at war.

123 Adams, Samuel, "The Rights of the Colonists," accessed on January 21, 2010 at http://history.hanover.edu/texts/adamss.html.

124 Greene, 187. 


\section{Bibliography}

Adams Family Papers Digital Archive accessed on January 29, 2011 at Http://www/masshist.org/digitaladams/aea/cfm/doc.cfm?id=D11\&numrecs=2\&archive=all\&hi=\&qyery $=1765 \% 20$ WEDNESDAY\&queryid=rec $1 \&$ start=1\&tag=text\#firstmatch.

Adams, Samuel.“The Rights of the Colonists.” Accessed on January 21, 2010 at http://history.hanover.edu/texts/adamss.html.

The Annual Register, or a View of the History, Politics, and Literature for the Year 1775. http://www.bodley.ox.ac.uk/cgibin/ilej/image1.pl?item=page \&seq=1\&size=1\&id=ar.1775.x.x.18.x.x.u1 .

Bailyn, Bernard. The Ideological Origins of the American Revolution. Harvard: Harvard University Press, 1992 (Originally published in 1967).

Cobett's Parliamentary History, Volume 16, (Oxford Digital Library), http://www2.odl.ox.ac.uk/gsdl/cgi-bin/library?e=d-000-00---0modhis06--00-0-0-0prompt-10---4------011--1-en-50---20-about---00001-001-1-1isoZz-8859Zz-1$\underline{0} \& \mathrm{a}=\mathrm{d} \& \mathrm{c}=$ modhis $06 \& \mathrm{cl}=\mathrm{CL} 1 \& \mathrm{~d}=$ modhis006-aap.

Connecticut Courant, September 30, 1765. Accessed November 12, 2010 at http://iw.newsbank.com/iwsearch/we/HistArchive?p_theme=ahnpdoc\&p_action=doc\&p_product=EANX\&p_nbid=B5BE58GMM TI4OTc3ODg3NS4zNjg5NzU6MToxMToxMjguMTExLjAuMA\&f_docref=image/v2:1080E0D856AD 30E8@EANX-10854F718F50B720-10854F71B8CDEE6010854F7269720FC8\&p_docref=image/v2:1080E0D856AD30E8@EANX-10854F718F50B72010854F71B8CDEE60-10854F7269720FC8\&p_docnum=-1

Connecticut Courant, November 17, 1766. Accessed May 31, 2010 at http://iw.newsbank.com/iw-

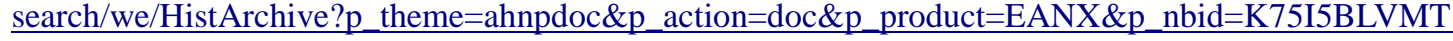
$\underline{\text { I3NTM1OTYwNi4yNjYxMjM6MToxMToxMjguMTExLjAuMA\&f_docref=image/v2:1080E0D856A }}$ D30E8@EANX-10854FF8108B36D8-10854FF87009AB2010854FF926F37368\&p docref=image/v2:1080E0D856AD30E8@EANX-10854FF8108B36D810854FF87009AB20-10854FF926F37368\&p_docnum=-1

Countryman, Edward. The American Revolution. Hill and Wang, 2003.

Dickinson, John. Empire and Nation: Letters from a Farmer in Pennsylvania (John Dickinson), ed. Forest McDonald (Indianapolis, Liberty Fund, 1999). Accessed May 31,2010 at http://oll.libertyfund.org/?option=com staticxt\&staticfile=show.php\%3Ftitle=690\&chapter=102302\&la yout $=$ html\&Itemid $=27$

Dulany, Daniel. Considerations on the Propriety of Imposing Taxes on the British Colonies (1765). Accessed on November 13, 2010 at http://httpserver.carleton.ca/ pking/docs/dulany.htm 
Green, Jack P. The Constitutional Origins of the American Revolution. Cambridge: Cambridge University Press, 2011.

Elton, G.R. ed. The Tudor Constitution. Cambridge, 1960.

Fischer, David Hackett. Paul Revere's Ride. Oxford: Oxford University Press, 1994.

Greene, Jack P. and Richard M. Jellison. "The Currency Act of 1764 in Imperial-Colonial Relations, 1764-1776." The William and Mary Quarterly, Third Series, Vol. 18, No. 4 (October 1961), 485-518.

Hurstfield, Joel. "Was There a Tudor Despotism After All?" Transactions of the Royal Historical Society (Fifth Series). Cambridge University Press (1967), 17: 83-108

Jefferson, Thomas. The Writings of Thomas Jefferson. Edited by Paul Leicester Ford. New York: G.P. Putnam's Sons, 1892. Accessed on January 15, 2011 at Http://books.google.com/books?id=vegqAAAAYAJ\&pg=PA3\&dq=The+Writings+of+Thomas+Jeffers on+Paul+Ford\&hl=en\&ei=kiFLTfHoO4-

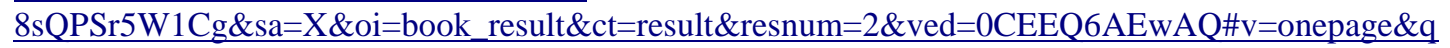
$\underline{\& \mathrm{f}=\text { false. }}$.

Journals of the House of Representatives of Massachusetts. Boston: Green and Russell, [1767-1768]. Accessed on June 28, 2010 at http://www.masshist.org/revolution/docviewer.php?old=1\&mode=nav\&item $\mathrm{id}=289$.

Linebaugh, Peter and Marcus Rediker. The Many-Headed Hydra: Sailors, Slaves, Commoners, and the Hidden History of the Revolutionary Atlantic. Boston: Beacon Press, 2000.

The Marlyland Gazette, August 1, 1766. Accessed November 12, 20101 at http://iw.newsbank.com/iwsearch/we/HistArchive?p theme=ahnpdoc\&p action=doc\&p_product=EANX\&p_nbid=B5BE58GMM TI4OTc3ODg3NS4zNjg5NzU6MToxMToxMjguMTExLjAuMA\&f_docref=image/v2:1080E0D856AD 30E8@EANX-10854F718F50B720-10854F71B8CDEE6010854F7269720FC8\&p docref=image/v2:1080E0D856AD30E8@EANX-10854F718F50B72010854F71B8CDEE60-10854F7269720FC8\&p docnum=-1

The Massachusetts Gazette Extraordinary, December, 1767. Number 3351, 24 December 1767. Boston: Published by Richard Draper, 1767. Accessed on June 28, 2010 at http://www.masshist.org/revolution/imageviewer.php?item id=256\&mode=small\&img step=1\&tpc=\#page1

Middlekauff, Robert. The Glorious Cause: The American Revolution, 1763-1789. Oxford: Oxford University Press, 2005. 
Morgan, Edmund S. The Birth of the Republic: 1763-1789. Chicago: University of Chicago Press, 1992.

Morgan, Edmund S. "Colonial Ideas of Parliamentary Power, 1764-1766." The William and Mary Quarterly, Third Series, Vol. 5, No. 3 (July, 1948), 311-341

Morgan, Edmund S. and Gwenda M. Morgan. The Stamp Act Crisis: Prologue To Revolution. The University of North Carolina Press, 1953.

Morgan, Gwenda. The Debate on the American Revolution. Manchester: Manchester University Press, 2007.

Namier, Louis. England in the Age of the American Revolution: London, 1930.

The New-Hampshire Gazette and Historical Chronicle, November 15, 1765. Accessed November 13, 2010 at http://iw.newsbank.com/iwsearch/we/HistArchive?p_theme=ahnpdoc\&p_action=doc\&p_product=EANX\&p_nbi d=A59S56AKMTI4OTc3NzgyMS4zOTA2MzU6MToxMToxMjguMTExLjAuMA\&f _docref=image/v2:103709D225B248A8@EANX-103CB68C10EB9F91103CB68C632BBE60103CB68D0AF25B59\&p_docref=image/v2:103709D225B248A8@EANX103CB68C10EB9F91-103CB68C632BBE60-103CB68D0AF25B59\&p_docnum=-1

The New-Hampshire Gazette and Historical Chronicle, November 22, 1765. Accessed November 13, 2010 at http://iw.newsbank.com/iwsearch/we/HistArchive?p_theme=ahnpdoc\&p_action=doc\&p_product=EANX\&p_nbid=B5FL5CQQM TI4OTc3NTQ3Ny4xMzcxMTM6MToxMToxMjguMTExLjAuMA\&f_docref=image/v2:103709D225B 248A8@EANX-103CB68D803A847B-103CB68DC1793FD1103CB68E82A17F14\&p docref=image/v2:103709D225B248A8@EANX-103CB68D803A847B103CB68DC1793FD1-103CB68E82A17F14\&p_docnum=-1

The Newport Mercury, May, 1766. Accessed May 31, 2010 at http://iw.newsbank.com/iw-

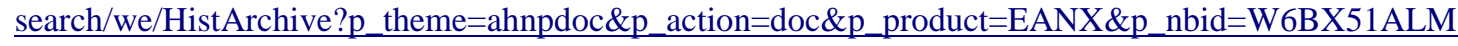
TI3NTM1ODYwOS42NDA1MDE6MToxMToxMjguMTExLjAuMA\&f_docref=image/v2:106AD2C0 F76EDF48@EANX-1070250E6D512E58-1070250EB76E85701070250F9A26CF18\&p_docref=image/v2:106AD2C0F76EDF48@EANX-1070250E6D512E581070250EB76E8570-1070250F9A26CF18\&p_docnum=-1

The Newport Mercury, November 18, 1765. Accessed November 12, 2010 at http://iw.newsbank.com/iwsearch/we/HistArchive?p_theme=ahnpdoc\&p_action=doc\&p_product=EANX\&p_nbi $\mathrm{d}=$ H61K5EDSMTI4OTc3NjU2MC41NTcwMzg6MToxMToxMjguMTExLjAuMA\&f _docref=image/v2:106AD2C0F76EDF48@EANX-107024DBB0D943A8107024DBE23E0D60-107024DCC9E493D8\&p_docnum=1\&toc=true \&p_docref=v2:106AD2C0F76EDF48@EANX-107024DBB0D943A8@ 107024DC05C6CA50-107024DCC9FB2918 
Pennsylvania Chronicle, December, 1767. Accessed May 31, 2010 at http://iw.newsbank.com/iw-

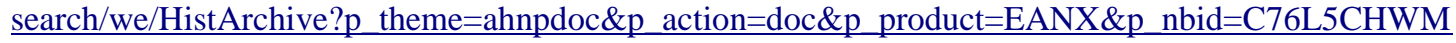
TI3NTM2MDEwOC42OTEzMzQ6MToxMToxMjguMTExLjAuMA\&f docref=image/v2:109CDAF4 EADF8660@EANX-10A87FC98458EA40-10A87FC9AFE8FFD810A87FCA8E6443E0\&p docref=image/v2:109CDAF4EADF8660@EANX-10A87FC98458EA4010A87FC9AFE8FFD8-10A87FCA8E6443E0\&p docnum=-1

Sommerville, J. P. Royalists and Patriots: Politics and Ideology in England 1603-1640. New York, Addison Wesley Longman, 1999.

The Statutes at Large of England and of Great Britain: From Magna Carta to the Union of the Kingdoms of Great Britain and Ireland (1811), vol. 4.

Unknown, “The Crisis,” Boston Evening Post, August, 1766. Accessed on May 31, 2010 at http://iw.newsbank.com/iw-

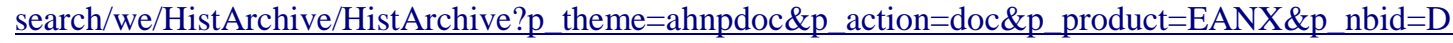
72C58JSMTI3NTM0OTY4MS4zODEwMzg6MToxMToxMjguMTExLjAuMA\&f docref=image/v2:1 089C792E64CF650@EANX-108B751A0A564938-108B751A16733140108B751A8DDC62B8\&p docref=image/v2:1089C792E64CF650@EANX-108B751A0A564938108B751A16733140-108B751A8DDC62B8\&p docnum=-1

The Virginia Gazette, March 7, 1766, accessed on December 12, 2010, http://research.history.org/DigitalLibrary/VirginiaGazette/VGIssueThumbs.cfm?IssueIDNo=66.PD.02

The Virginia Gazette, March 21, 1766, accessed on December 12, 2010, http://research.history.org/DigitalLibrary/VirginiaGazette/VGImagePopup.cfm?ID=1490\&Res=HI

The Virginia Gazette, May 16, 1766, accessed on December 12, 2010, http://research.history.org/DigitalLibrary/VirginiaGazette/VGImagePopup.cfm?ID=1655\&Res=HI

The Virginia Gazette, July 18, 1766, accessed December 22, 2010, http://research.history.org/DigitalLibrary/VirginiaGazette/VGIssueThumbs.cfm?IssueIDNo=66.PD.22

The Virginia Gazette, April 14, 1769, accessed on January 13, 2011, Http://research.history.org/DigitalLibrary/VirginiaGazette/VGimagePopup.cfm?ID=2550\&RES=HI\&C FID=9090659\&CFTOKEN=68247007

The Virginia Gazette, June 8, 1769, accessed on January 13, 2011, Http://research.history.org/DigitalLibrary/VirginiaGazette/VGImagePopup.cfm?ID=2 $385 \&$ Res $=$ HI $\&$ CFID $=10788416 \&$ CFTOKEN=35918089

The Virginia Gazette, November 10, 1769, accessed on January 13, 2011, Http://research.history.org/DigitalLibrary/VirginiaGazette/VGImagePopup.cfm?ID=2112\&Res=HI\&CF $\underline{\mathrm{ID}=10788416 \& \mathrm{CFTOKEN}=35918089}$

"The Virginia Stamp Act Resolution," 1765. Accessed on February 5, 2011 at Http://www.ushistory.org/declaration/related/vsa65.htm 
Wolkins, George G. "The Seizure of John Hancock's Sloop Liberty". Proceedings of the Massachusetts Historical Society 55 (1923), 239-84.

Wood, Gordon S. The American Revolution: A History. New York: Modern Library, 2003.

Wood, Gordon S. The Creation of the American Republic, 1776-1787. The University of North Carolina Press, 1998 (Originally published in 1969).

Wood, Gordon S. The Radicalism of the American Revolution. New York: Vintage Books, 1993.

Yale Law School, “Avalon Project: Documents in Law, History, and Diplomacy,” Lillian Goldman Law Library, http://avalon.law.yale.edu/18th_century/currency_act_1764.asp.

Yale Law School, “Avalon Project: Documents in Law, History, and Diplomacy,” Lillian Goldman Law Library, http://avalon.law.yale.edu/18th_century/sugar_act_1764.asp.

Yale Law School, “Avalon Project: Documents in Law, History, and Diplomacy,” Lillian Goldman Law Library, http://avalon.law.yale.edu/18th_century/proc1763.asp.

Yale Law School, “Avalon Project: Documents in Law, History, and Diplomacy,” Lillian Goldman Law Library, http://avalon.law.yale.edu/medieval/magframe.asp

Yale Law School, “Avalon Project: Documents in Law, History, and Diplomacy," Lillian Goldman Law Library, http://avalon.law.yale.edu/18th_century/newyork_non_importation_1765.asp.

Yale Law School, “Avalon Project: Documents in Law, History, and Diplomacy,” Lillian Goldman Law Library, http://avalon.law.yale.edu/18th_century/ct_resolutions_1765.asp.

Yale Law School, “Avalon Project: Documents in Law, History, and Diplomacy,” Lillian Goldman Law Library, http://avalon.law.yale.edu/18th_century/petition_va_1764.asp.

Yale Law School, “Avalon Project: Documents in Law, History, and Diplomacy,” Lillian Goldman Law Library, http://avalon.law.yale.edu/18th_century/petition_mass_1764.asp.

Yale Law School, “Avalon Project: Documents in Law, History, and Diplomacy,” Lillian Goldman Law Library, http://avalon.law.yale.edu/18th_century/stamp_act_1765.asp.

Yale Law School, “Avalon Project: Documents in Law, History, and Diplomacy,” Lillian Goldman Law Library, http://avalon.law.yale.edu/18th_century/resolu65.asp.

Yale Law School, “Avalon Project: Documents in Law, History, and Diplomacy,” Lillian 
Goldman Law Library, http://avalon.law.yale.edu/18th_century/newyork_non_importation_1765.asp.

Yale Law School, “Avalon Project: Documents in Law, History, and Diplomacy,” Lillian Goldman Law Library, http://avalon.law.yale.edu/18th_century/penn_assembly 1765.asp.

Yale Law School, “Avalon Project: Documents in Law, History, and Diplomacy,” Lillian Goldman Law

Library, http://avalon.law.yale.edu/18th_century/declaratory_act 1766.asp.

Yale Law School, “Avalon Project: Documents in Law, History, and Diplomacy,” Lillian Goldman Law Library, http://avalon.law.yale.edu/18th_century/townsend_act_1767.asp

Yale Law School, “Avalon Project: Documents in Law, History, and Diplomacy,” Lillian Goldman Law Library, http://avalon.law.yale.edu/18th_century/charleston_non_impotation_1769.asp

Yale Law School, “Avalon Project: Documents in Law, History, and Diplomacy,” Lillian Goldman Law Library, http://avalon.law.yale.edu/18th_century/boston_non_importation_1768.asp

Yale Law School, “Avalon Project: Documents in Law, History, and Diplomacy,” Lillian Goldman Law Library, http://avalon.law.yale.edu/17th century/england.asp 